\title{
Habilitacje w Polsce Ludowej. \\ Część 1. Warunki i przebieg habilitacji w prawie szkół wyższych
}

\section{Wprowadzenie}

W Polsce międzywojennej pomyślne zakończenie postępowania habilitacyjnego wiązano z prawem wykładania (veniam legendi). W żadnym razie nie prowadziło ono do uzyskania stopnia naukowego. Rozwiązanie takie przyjęły obie ustawy o szkołach akademickich z 1920 i 1933 r. ${ }^{1}$ Obie też przyznanie kandydatowi veniam legendi rezerwowały wyłącznie dla szkół akademickich. Od tego, ówcześnie zakładanego, standardu nie odstąpiono w pierwszych latach Polski Ludowej. Przyjęte w 1947 r. dekretem $^{2}$ rozwiązania nadal nie wiązały habilitacji z nadaniem stopnia naukowego, aczkolwiek postępowanie habilitacyjne nieco zmodyfikowano. Wzorem rozwiązań wcześniejszych dekret wprawdzie dalej szkoły wyższe nazywał szkołami akademickimi i dla nich zachował prawo habilitowania, jednak ich wykaz zrewidował, a ponadto prawo habilitowania, w sytuacjach określonych dekretem, powierzył także Radzie Głównej do Spraw Nauki i Szkolnictwa Wyższego 3 .

Od postępowań habilitacyjnych odstąpiono z początkiem 1952 r. wraz z wdrożeniem ustawy z 1951 r. o szkołach wyższych i o pracownikach

${ }^{1}$ Ustawa z dnia 13 VII 1920 r. o szkołach akademickich (Dz.U. RP Nr 72, poz. 494 ze zm.) oraz Ustawa z dnia 15 III 1933 r. o szkołach akademickich (tekst jedn. Dz.U. RP $1938 \mathrm{Nr} 1$, poz. 6 ze zm.).

2 Dekret z dnia 28 X 1947 r. o organizacji nauki i szkolnictwa wyższego (Dz.U. Nr 66, poz. 415).

${ }^{3}$ W dalszej części opracowania nazywanej „Radą Główną” lub „Radą”. 
nauki ${ }^{4}$. Zmiany dalej idące przyniosły dopiero lata następne. Zapoczątkowała je ustawa z 1958 r. o szkołach wyższych ${ }^{5}$. Aktem tym nie tylko przywrócono postępowanie habilitacyjne, ale ponadto pomyślne jego zakończenie powiązano z uzyskaniem wyższego stopnia naukowego. Prawa do habilitowania nie pozostawiono wyłącznie szkołom wyższym. Postępowania habilitacyjne mogły przeprowadzać także placówki naukowe Polskiej Akademii Nauk (PAN) oraz instytuty naukowe istniejące poza szkołami wyższymi. Prawa tego nie zachowano natomiast dla Rady Głównej ${ }^{6}$. Ponownej ocenie poddano również zakres dyscyplin naukowych, w obrębie których mogły być nadawane wyższe stopnie naukowe.

Od 1965 r. prawo nadawania stopni naukowych poddano odrębnej regulacji - Ustawie z dnia 31 marca 1965 r. o stopniach naukowych i tytułach naukowych ${ }^{7}$. Konsekwencją tego zabiegu legislacyjnego było wyłączenie spraw stopni naukowych (także tytułów naukowych) z ustawodawstwa o szkolnictwie wyższym. Nie bez uzasadnienia więc rozwiązania wprowadzone kolejną (z 1982 r.) ustawą ${ }^{8}$ reformująca szkolnictwo wyższe jedynie marginalnie dotykały kwestii habilitacji i sytuacji prawnej osób habilitowanych w szkołach wyższych i poza nimi.

W ten sposób wykształciły się dwie drogi normowania spraw dotyczących stopni naukowych. Pierwsza zawężona wyłącznie do aktów rangi ustawowej regulujących sprawy szkolnictwa wyższego w ogóle, w tym nadawanie stopni naukowych. Druga - ograniczona jedynie do prawnej regulacji stopni (tytułów) naukowych. Oczywiście, żaden z aktów rangi ustawowej ówcześnie wydanych nie wyczerpywał zakresu unormowań. Warunki nadawania stopni naukowych oraz przeprowadzania postępowań habilitacyjnych określały akty wykonawcze wydane na ich podstawie, o ile przepisy intertemporalne nie przyjęły tu innego rozwiązania.

Dla osób z pomyślnie zakończonym postępowaniem habilitacyjnym przyjęte wtedy rozwiązania nie były jednotorowe. W Polsce międzywojnia, a w ślad za nią także w pierwszych latach Polski Ludowej habilitację wiązano wyłącznie z prawem - wykładania, od 1947 r. - nauczania. Począwszy od roku 1958, tendencję tę niemal odwrócono. Pomyślnie

${ }^{4}$ Ustawa z dnia 15 XII 1951 r. o szkolnictwie wyższym i pracownikach nauki (Dz.U. $1952 \mathrm{Nr} 6$, poz. 38 ze zm.). Ustawa ta weszła w życie z dniem 7 II 1952 r.

${ }^{5}$ Ustawa z dnia 5 XI 1958 r. o szkołach wyższych (Dz.U. Nr 68, poz. 336 ze zm.).

${ }^{6}$ Rada Główna w ciągu sześciu miesięcy od dnia wejścia w życie ustawy z 1958 r. o szkołach wyższych miała się ukonstytuować zgodnie z postanowieniami tej ustawy (art. 142).

${ }^{7}$ Dz.U. Nr 14, poz. 101.

${ }^{8}$ Ustawa z dnia 4 V 1982 r. o szkolnictwie wyższym (Dz.U. Nr 14, poz. 113 ze zm.). 
zakończone postępowanie habilitacyjne prowadziło do nabycia stopnia naukowego docenta, od 1968 r. - stopnia naukowego doktora habilitowanego. $\mathrm{W}$ jego efekcie osobie habilitowanej także przysługiwało prawo do samodzielnego prowadzenia wykładów i innych zajęć dydaktycznych oraz kierowania pracami samodzielnymi. A priori można więc założyć, że różnica tkwiła w różnych systemach prawnych, ówcześnie wiążących habilitację ze stopniem naukowym bądź nieczyniących tego. Dopiero ustalenie warunków wszczęcia postępowania habilitacyjnego i jego przebiegu, w każdym z okresów objętych analizą, może potwierdzić lub zaprzeczyć przyjętemu założeniu, a w efekcie zarazem ukazać ratio legis rozwiązań minionych lat Polski Ludowej. Nie byłby to jednak obraz pełny bez uwzględnienia rozmiarów bazy szkolnictwa wyższego, bez której dalsze kształcenie ówczesnej kadry naukowej nie byłoby możliwe. Ich brzegowe granice wyznaczały te szkoły wyższe (później także placówki i instytuty naukowe), którym prawo habilitowania nadano, oraz zakresy (gałęzie) nauk z prawem tym korespondujące.

Wbrew oczekiwaniom rozstrzygnięcia $\mathrm{w}$ tym zakresie nie były ciągiem prostych działań. I choć rok 1965 wyznaczył wyraźną linię demarkacyjną w sprawach dotyczących przewodów habilitacyjnych i warunków nadawania wyższego stopnia naukowego, począwszy od roku 1958 niemalże ukształtowanych od nowa, lata 1945-1990 wyraźnie emanowały poszukiwaniem rozwiązań prawnych dostosowanych do warunków ówczesnej Polski, zarówno tej sprzed roku 1965, jak i tej po nim. Nie bez racjonalnej przyczyny, a także ze względu na dopuszczalne ramy opracowania problematyka habilitacji określonych przepisami ustawy o stopniach naukowych i tytułach naukowych będzie przedmiotem drugiej części opracowania.

\section{Postępowania habilitacyjne w pierwszych latach Polski Ludowej}

Wraz z zakończeniem II wojny światowej w Polsce postępowania habilitacyjne nadal normowały przepisy prawne wprowadzone w latach trzydziestych okresu Polski międzywojennej, tj. Ustawa z dnia 15 marca 1933 r. o szkołach akademickich9 oraz Rozporządzenie Ministra Wyznań

${ }^{9}$ W brzmieniu nadanym Obwieszczeniem Ministra Wyznań Religijnych i Oświecenia Publicznego z dnia 8 XI 1947 r. w sprawie ogłoszenia jednolitego tekstu ustawy z dnia 15 III 1933 r. o szkołach akademickich (Dz.U. RP 1938 Nr 1, poz. 6). 
Religijnych i Oświecenia Publicznego z dnia 21 kwietnia 1936 r. w sprawie postępowania habilitacyjnego w państwowych szkołach akademic$\mathrm{kich}^{10}$. Ustawa przeprowadzenie habilitacji pozostawiała w gestii rad wydziałowych, przy zastrzeżeniu wprowadzonym rozporządzeniem z 1936 r.: tylko w zakresie gałęzi nauki reprezentowanej przez jedną z katedr danego wydziału. Wyjątek w tej mierze był dopuszczalny wyłącznie za zgodą ministra wyznań religijnych i oświecenia publicznego, i to wtedy, gdy dana gałąź nauki nie mogła być reprezentowana przez żadną z katedr szkół akademickich w Polsce. Wyłącznie ustawa zastrzegała, że warunkiem dopuszczenia do habilitowania jest posiadanie stopnia doktora. Zarazem od tego obowiązku dopuszczała zwolnienie przez radę wydziałową wybitnych fachowców, a wyjątkowo także wybitnych badaczy naukowych. Z kolei wyłącznie rozporządzenie z $1936 \mathrm{r}$. określało warunki wymagane od kandydata zamierzającego się habilitować ${ }^{11}$. Oba zaś akty prawne ${ }^{12}$ określały przebieg postępowania habilitacyjnego obejmującego:

1. ocenę kwalifikacji naukowych (artystycznych) kandydata na podstawie zbadania wartości jego pracy habilitacyjnej, poprzedzonej rozpatrzeniem przez radę wydziałową kwalifikacji osobistych kandydata. Tylko w przypadku pozytywnej oceny jego kwalifikacji osobistych (przegłosowanej w zasadzie jawnie) rada wydziałowa wybierała trzech lub w razie potrzeby większą liczbę referentów (później nazywanych recenzentami) spośród profesorów zwyczajnych, nadzwyczajnych, honorowych oraz tytularnych, wykładających ten sam przedmiot lub przedmioty pokrewne, zarówno ze swego grona, jak i innych wydziałów

${ }^{10}$ Dz.U. RP Nr 38, poz. 290.

${ }^{11}$ Od kandydata zamierzającego się habilitować rozporządzeniem z 1936 r. wymagano: złożenia dziekanowi podania skierowanego do rady wydziałowej tego wydziału, na którym kandydat zamierzał uzyskać prawo wykładania. W nim miał wymienić naukę lub taką jej część, którą można uważać za przedmiot w sobie zamknięty, w zakresie którego mógłby wykładać. Do podania należało dołączyć życiorys, dokumenty osobiste, spis wszystkich prac naukowych dotychczas ogłoszonych wraz z odbitkami oraz trzy egzemplarze ogłoszonej drukiem rozprawy habilitacyjnej.

${ }^{12}$ Jedynie gdy temat pracy habilitacyjnej stanowił tajemnicę państwową, postępowanie habilitacyjne odbywało się ze zmianami określonymi regulaminem wprowadzonym przez ministra wyznań religijnych i oświecenia publicznego ( $\$ 1$ Rozporządzenia Ministra Wyznań Religijnych i Oświecenia Publicznego z dnia 26 VII 1939 r. o sposobie postępowania habilitacyjnego w państwowych szkołach akademickich (Dz.U. Nr 69, poz. 468). Przy ustaleniu, co stanowi tajemnicę państwowa, minister miał stosować odpowiednio art. 9 § 1 Rozporządzenia Prezydenta Rzeczypospolitej z dnia 24 X 1934 r. o niektórych przestępstwach przeciwko bezpieczeństwu Państwa (Dz.U. RP Nr 94, poz. 851). 
lub innych szkół akademickich oraz szkół akademickich zagranicznych. Na podstawie dokonanej przez referentów oceny pracy habilitacyjnej (wnoszącej istotny postęp w nauce i świadczącej o samodzielności naukowego myślenia autora oraz znajomości literatury przedmiotu, z zastrzeżeniem braku możności uznania za taką rozprawy doktorskiej lub jej przeróbki ${ }^{13}$ ) oraz całości dorobku naukowego kandydata rada wydziałowa dopuszczała bądź nie do dalszych stadiów przewodu habilitacyjnego;

2. dyskusję habilitacyjną, którą można było objąć nie tylko temat pracy habilitacyjnej, ale także całość przedmiotu, z którego kandydat się habilitował. W dyskusji mogli wziąć udział, poza referentami, także członkowie rady wydziałowej oraz profesorowie i referenci zaproszeni z innych wydziałów lub innych szkół akademickich. Rada wydziałowa mogła kandydata wyjątkowo zwolnić od oceny kwalifikacji naukowych (artystycznych);

3. wygłoszenie wykładu habilitacyjnego wobec rady wydziałowej, którego tematem miał być zatwierdzony przez nią jeden $z$ dwóch tematów przedstawionych przez kandydata. Wykład habilitacyjny miał dowieść posiadania przez kandydata umiejętności zwięzłego i jasnego przedstawienia zagadnień naukowych. Tu także rada wydziałowa wyjątkowo mogła kandydata zwolnić od wypełnienia tego aktu habilitacji.

Przy założeniu dochowania porządku poszczególnych stadiów postępowania habilitacyjnego (i obowiązku ich protokołowania), na radzie wydziałowej spoczywał obowiązek podjęcia uchwał dla każdego z nich oddzielnie, $w$ każdym przypadku zapadłych głosami obecnych członków rady wydziałowej. W razie niepomyślnej uchwały rady co do pierwszego lub drugiego stadium odpadała możliwość dalszego przeprowadzania przewodu habilitacyjnego. W razie zaś jedynie niepomyślnej oceny wykładu habilitacyjnego rada wydziałowa mogła dopuścić do wygłoszenia innego wykładu, zarazem pozwalając kandydatowi na przedstawienie nowego tematu, wymagającego zatwierdzenia przez nią.

O ostatecznym wyniku habilitacji rada wydziałowa rozstrzygała zwykłą większością głosów obecnych członków wydziału (przy równej liczbie głosów za i przeciw wynik głosowania uznawano za negatywny). W efekcie pomyślnej uchwały co do każdego z trzech stadiów habilitacji (o ile nie wprowadzono prawem przewidzianych wyłączeń) rada

\footnotetext{
${ }^{13}$ Praca habilitacyjna miała być wydrukowana w języku polskim lub w języku wykładowym przedmiotu ( $\$ 6$ rozporządzenia z 1936 r.).
} 
wydziałowa na wniosek referentów podejmowała uchwałę o nadaniu kandydatowi prawa wykładania. Uchwałą tą zarazem określano dziedzinę nauki lub jej część, stanowiącą zamkniętą w sobie całość przedmiotu, na jaką rozciągało się prawo wykładania. Uchwała rady wydziałowej (nadająca kandydatowi tytuł i prawa docenta) wymagała zatwierdzenia przez ministra wyznań religijnych i oświecenia publicznego po wysłuchaniu opinii senatu ${ }^{14}$. Wynikające $z$ uchwały prawo wykładania gasło, jeżeli docent: (1) nie skorzystał z niego przez dwa następujące po sobie lata akademickie, chyba że $\mathrm{w}$ tym okresie korzystał z urlopu przyznanego przez ministra na podstawie wniosku rady wydziałowej; (2) został mianowany profesorem nadzwyczajnym lub zwyczajnym na innym wydziale lub w innej szkole akademickiej. Na jego prośbę prawo to mogło być przez radę wydziałową utrzymane.

Taki stan prawny, odnoszony do postępowań habilitacyjnych, w 1945 r. zastał polskie szkoły akademickie. Działania zmierzające do zachowania habilitacji minister oświaty podją już w następnym miesiącu po zakończeniu II wojny światowej. I choć w swym rozporządzeniu z dnia 25 czerwca 1945 r. ${ }^{15}$ nie określał nowych zasad i warunków postępowania habilitacyjnego (rozporządzeniem tym zmieniał jedynie niektóre postanowienia rozporządzenia ministra wyznań religijnych i oświecenia publicznego z dnia 21 kwietnia 1936 r.), jego waga była niezwykle donośna. Dowodziła potrzeby zachowania pewnej ciągłości $\mathrm{w}$ procesie habilitowania, tak istotnego wtedy dla odbudowy i poszerzania potencjału bardzo uszczuplonej wojną kadry naukowej zdolnej do wykładania (nauczania) w szkołach akademickich. To że zachowano nim warunki i zasady określone prawem Polski międzywojennej ${ }^{16}$, bezsprzecznie było zrozumiałe. Rok 1945 nie był czasem usposabiającym do wdrożenia w Polsce szeroko zakrojonych reform, w tym tych dotyczących szkół wyższych. Dwie zmiany wprowadzone rozporządzeniem z czerwca 1945 r. zaadresowano do rad wydziałowych. Zgodnie z nimi rada wydziałowa mogła: (1) przeprowadzać habilitację tylko w zakresie

\footnotetext{
${ }^{14}$ W szkołach artystycznych i w zakresie niektórych przedmiotów (od 1945 r. w zakresie przedmiotów nauki stosowanej) w innych szkołach tytuł i uprawnienia docenta mogły być uzyskiwane na podstawie wniosku komisji kwalifikacyjnej, powołanej przez radę wydziałową (art. 29 ust. 1 ustawy z dnia 15 III 1933 r.).

${ }^{15}$ Rozporządzenie Ministra Oświaty z dnia 25 VI 1945 r. w sprawie postępowania habilitacyjnego w państwowych szkołach akademickich (Dz.U. Nr 24, poz. 139).

${ }^{16}$ O nabyciu w Polsce międzywojennej w drodze habilitacji prawa wykładania zob. K. Wojtczak, O stopniach naukowych i veniam legendi w II Rzeczypospolitej (Część II), „Studia Prawa Publicznego" 2014, nr 4(8), s. 22-30.
} 
gałęzi nauki reprezentowanej przez jedną z katedr danego wydziału lub w razie jej braku (co stanowiło zmianę dotychczasowej treści) przez katedrę pokrewną. Wyjątek w tej mierze był dopuszczalny za zgodac ministra oświaty jedynie wtedy, gdy dana gałąź nauki nie mogła być reprezentowana przez żadną z katedr polskich szkół akademickich ani przez katedrę pokrewną (słowa dodane); (2) zwolnić od obowiązku złożenia odbitek prac naukowych (czego nie przewidywało rozporządzenie z 1936 r.), jeżeli wskutek działań wojennych nie było to wykonalne; rada mogła przyjąć rozprawę habilitacyjną napisaną w języku obcym, z zastrzeżeniem złożenia jej przed dniem 31 grudnia 1948 r. Do tego dnia rozprawa habilitacyjna mogła być złożona w rękopisie. Rozporządzenie z 1936 r. wymagało złożenia pracy habilitacyjnej wyłącznie ogłoszonej drukiem.

Potwierdzenie, że nie był to czas spokojnej oceny, stanowią także niepokoje i niezrozumienie obowiązujących regulacji przez ówczesnych rektorów szkół akademickich. Nie bez powodu podsekretarz stanu $\mathrm{w}$ ministerstwie oświaty $\mathrm{w}$ drodze okólnika ${ }^{17}$ przypomniała i zaznaczyła, że do wniosków o zatwierdzenie habilitacji poza uchwałą rady wydziałowej i senatu winny być zawsze dołączone: bardzo dokładne życiorysy, zwłaszcza w odniesieniu do okresu ostatniej wojny (19391945), szczegółowe referaty zawierające ocenę działalności naukowej, dydaktycznej i społecznej, spis prac naukowych i zgoda kandydata na objęcie katedry. Przy przedkładaniu wniosków o zatwierdzanie habilitacji odwoływała się do odpowiednich postanowień rozporządzenia z dnia 21 kwietnia 1936 r., z uwzględnieniem zmian przyjętych rozporządzeniem z 1945 r., zakładającym przy wyborze referentów ich dobór wyłącznie spośród profesorów (mianowanych) wykładających ten sam przedmiot lub przedmioty pokrewne, $\mathrm{z}$ wyraźnym zastrzė̇eniem, że ocena pracy habilitacyjnej i dorobku naukowego kandydata powinna być przedstawiona przez każdego z referentów oddzielnie, a nie zbiorowo. Podsekretarz stanu w okólniku podkreśliła także, że używanie tytułu docenta mogło mieć miejsce nie wcześniej niż od chwili zatwierdzenia habilitacji przez ministra oświaty ${ }^{18}$.

${ }^{17}$ Okólnik Nr 18 z dnia 2 VI 1947 r. o sposobie postępowania przy obsadzaniu katedr i zatwierdzaniu habilitacji w szkołach akademickich oraz o używaniu tytułu profesora lub docenta (Dz.Urz. Ministerstwa Oświaty Nr 6, poz. 141).

${ }_{18}$ Tylko w przypadku zatwierdzonej habilitacji i jedynie spośród docentów państwowych szkół akademickich minister oświaty mógł na wniosek rady wydziałowej lub z własnej inicjatywy, po wysłuchaniu jej opinii, mianować docentem etatowym państwowej 
Do postępowań habilitacyjnych w pozostałym zakresie miały zatem w pełni zastosowanie przepisy Ustawy z dnia 15 marca 1933 r. o szkołach akademickich oraz wydanego na jej podstawie rozporządzenia z 1936 r., wraz z przyjętymi w 1945 r. zmianami. W odniesieniu do docentów etatowych także przepisy Rozporządzenia Prezydenta Rzeczypospolitej z dnia 24 lutego 1928 r. o stosunku służbowym profesorów państwowych szkół akademickich i pomocniczych sił naukowych tych szkół ${ }^{19}$, w brzmieniu nadanym dwoma dekretami z dnia 16 listopada 1945 r. $^{20}$

Z końcem października 1947 r. dekretem Rady Państwa ${ }^{21}$ wdrożono pierwszą $z$ powojennych reform szkolnictwa wyższego. I choć jej znaczenie na ówczesne czasy przemian w zakresie szkolnictwa akademickiego było duże, tej rangi nie miały postanowienia odnoszone do postępowań habilitacyjnych. Wzorem Polski międzywojennej habilitacji nie wiązano ze stopniem naukowym, jej pomyślne zakończenie dawało kandydatowi prawo nauczania ${ }^{22}$, i to w tej szkole akademickiej, dla której zostało uzyskane wraz z tytułem docenta tej szkoły.

Dekret jedynie generalnie określał, które ze szkół akademickich mają prawo habilitowania - i były to tylko te, które $\mathrm{w}$ danej gałęzi nauki lub w gałęziach pokrewnych miały odpowiednie warunki pracy naukowej. Zarazem nadanie szkole akademickiej tego prawa pozostawiał w gestii ministra oświaty za zgodą Rady Głównej. Minister niewiele ponad pół roku później mocą swego zarządzenia ${ }^{23}$ nadał prowizorycznie prawo

szkoły akademickiej - zob. Dekret z dnia 16 XI 1945 r. o stosunku służbowym i uposażeniu etatowych docentów państwowych szkół akademickich (Dz.U. Nr 8, poz. 309).

${ }^{19}$ Obwieszczenie Ministra Wyznań Religijnych i Oświecenia Publicznego z dnia 21 VII 1933 r. w sprawie ogłoszenia jednolitego tekstu rozporządzenia Prezydenta Rzeczypospolitej z dnia 24 II 1928 r. o stosunku służbowym profesorów państwowych szkół akademickich i pomocniczych sił naukowych tych szkół (Dz.U. Nr 76, poz. 551).

${ }^{20}$ Chodzi tu o Dekret z dnia 16 XI 1945 r. o zmianie przepisów dotyczących szkół akademickich i stosunku służbowego profesorów i pomocniczych sił naukowych tych szkół (Dz.U. Nr 56, poz. 313) oraz o Dekret z dnia 16 XI 1945 r. o stosunku służbowym i uposażeniu etatowych docentów państwowych szkół akademickich (Dz.U. Nr 56, poz. 314).

${ }^{21}$ Dekret z dnia 28 X 1947 r. o organizacji nauki i szkolnictwa wyższego. Dekretem tym uchylono ustawę z dnia 15 III 1933 r. o szkołach akademickich, a także wszelkie inne przepisy w sprawach nim unormowanych (art. 119 ust. 2 pkt 1 i 6 ).

${ }^{22}$ O różnicy treści pojęć: nauczanie - kształcenie zob. K. Wojtczak, Prawne determinanty procesu kształcenia w szkołach wyższych w latach 1920-1990 (Część I), "Studia Prawa Publicznego" 2013, nr 4, s. 55 i n.

${ }^{23}$ Zarządzenie Ministra Oświaty z dnia 3 VII 1948 r. w sprawie tymczasowego nadania prawa habilitowania państwowym szkołom akademickim (Dz.Urz. Ministerstwa Oświaty Nr 9, poz. 146). 
habilitowania tylko tym państwowym szkołom akademickim, które je miały w dniu wejścia w życie dekretu, tj. w dniu 30 października 1947 r. ${ }^{24}$, z zastrzeżeniem, że w szkołach tych są obsadzane przez zwyczajnych lub nadzwyczajnych profesorów katedry odpowiadające gałęziom nauki, w których habilitacja mogła być dokonana. I był to warunek bezwzględny. $W$ razie opróżnienia katedry prawo habilitowania ulegało zawieszeniu do czasu obsadzenia katedry przez profesora zwyczajnego lub nadzwyczajnego.

Prawa habilitowania po raz pierwszy nie zastrzeżono wyłącznie dla szkół akademickich. Wyposażono w nie także Radę Główną. O ile $\mathrm{w}$ szkołach akademickich prawo to mogło być realizowane ${ }^{25} \mathrm{~W}$ zakresie nadanym przez ministra oświaty za zgodą Rady Głównej, Rada ta prawo habilitowania wypełniała we własnym zakresie działania (habilitacja centralna), za pośrednictwem sekcji specjalnej, powoływanej przez Prezydium tej Rady ${ }^{26}$ dla każdego przypadku oddzielnie ${ }^{27}$, niezależnie od działań podejmowanych w zakresie habilitowania w wyjątkowych sytuacjach (w następstwie złożonego przez kandydata odwołania, zażalenia - na poszczególnych etapach postępowania).

Wzorem rozwiązań Polski międzywojennej warunkiem potrzebnym do habilitowania się było posiadanie stopnia doktora. Wprawdzie i tu dekret przewidywał możliwość odstąpienia od tego warunku (przez ministra oświaty za zgodą Rady Głównej), lecz zwolnieniem mogli być

${ }^{24}$ O szkołach akademickich działających do 1939 r. i utworzonych po II wojnie światowej w okresie przed wejściem w życie dekretu z 1947 r. zob. K. Wojtczak, Wkwestii wyższego stopnia naukowego doktora w Polsce Ludowej, "Studia Prawa Publicznego" 2016, nr 4(16), s. 36-41.

${ }^{25}$ Habilitację przeprowadzała rada wydziałowa wydziału obejmującego w swym programie studiów tę gałąź nauki, w zakresie której szkoła akademicka uzyskała prawo habilitowania ( 33 Rozporządzenia Ministra Oświaty z dnia 3 VII 1948 r. wydane w porozumieniu z Ministrem Zdrowia w sprawie postępowania habilitacyjnego - Dz.U. Nr 41, poz. 298).

${ }^{26}$ Prezydium Rady Głównej Szkolnictwa Wyższego tworzyli: przewodniczący Rady, jego zastępca, sekretarz generalny i dwaj inni członkowie wybrani przez Radę z jej grona. Przewodniczącym Rady był z urzędu minister oświaty lub reprezentujący go podsekretarz stanu (art. $11 \mathrm{w}$ zw. z art. 10 ust. 1 dekretu z 1947 r.).

${ }^{27}$ Sekcja składała się z przewodniczącego i co najmniej czterech członków, powołanych spośród profesorów i docentów szkół akademickich lub też innych wybitnych pracowników naukowych, czynnych w dziedzinie nauki, z której kandydat zamierzał się habilitować bądź w dziedzinach pokrewnych. W skład sekcji mogli być również powołani, w liczbie nieprzekraczającej jednej czwartej ogółu członków sekcji, wybitni praktycy z dziedziny odpowiadającej specjalności naukowej kandydata. Postanowienia dotyczące rad wydziałowych odnosiły się odpowiednio do sekcji specjalnych Rady Głównej. 
objęci wyłącznie (co należy uznać za trafne) wybitni badacze naukowi (na mocy ustawy z 1933 r. - wybitni fachowcy, a wyjątkowo także wybitni badacze naukowi). Tak jak w rozwiązaniach wcześniejszych przewód habilitacyjny poprzedzała ocena kwalifikacji osobistych kandydata, a jego podstawą była rozprawa naukowa (habilitacyjna) opublikowana przed rozpoczęciem przewodu habilitacyjnego, przedłożona wraz z podaniem o wszczęcie tego przewodu. Po przyjęciu podania ${ }^{28}$ rada wydziałowa w głosowaniu tajnym orzekała, czy kandydat miał dostateczne kwalifikacje osobiste do nauczania w danej szkole akademickiej. Decyzja negatywna miała być umotywowana i podana do wiadomości kandydatowi.

Zgodnie z dekretem i Rozporządzeniem Ministra Oświaty z dnia 3 lipca 1948 r. wydanym w porozumieniu z Ministrem Zdrowia w sprawie postępowania habilitacyjnego ${ }^{29}$ postępowanie to zmierzało do oceny kwalifikacji naukowych i pedagogicznych kandydata (jedynie po pozytywnej ocenie jego kwalifikacji osobistych) i obejmowało trzy kolejne stadia:

1. ocenę wartości naukowej rozprawy habilitacyjnej i innych publikacji kandydata - wzorem rozwiązań wcześniejszych zarówno dekret, jak i rozporządzenie z 1948 r. nie wskazywały kryteriów oceny innych publikacji naukowych kandydata. W ślad za nimi określały natomiast wymogi stawiane pracom habilitacyjnym. W odróżnieniu od rozwiązań wcześniejszych wymogi te podwyższono. Za im odpowiadające mogła być uznana tylko ta praca habilitacyjna, która stanowiła samodzielny dorobek pracy badawczej kandydata, pomnażający ogólny dorobek nauki w tej dziedzinie, i świadczyła o opanowaniu przez niego metod badania naukowego właściwych dla danej gałęzi nauki. Dla dokonania

${ }^{28}$ Podanie przyjmowano, o ile zawierało określenie nauki lub samodzielnej jej części, w której kandydat zamierzał uzyskać prawo nauczania, jeśli do niego dołączono: szczegółowy życiorys kandydata ze szczególnym uwzględnieniem przebiegu studiów i pracy naukowej; dowód uzyskania stopnia doktora; dziesięć egzemplarzy opublikowanej pracy habilitacyjnej; wykaz innych opublikowanych prac naukowych kandydata, a w miarę możności także po jednym egzemplarzu tych prac. Gdy złożone podanie warunkom tym nie odpowiadało, dziekan wydziału (gdy chodzi o szkoły akademickie), minister oświaty (w przypadku habilitacji przeprowadzanych przez Radę Główną) mogli zażądać usunięcia braków w wyznaczonym terminie, a w razie jego bezskutecznego upływu podanie odrzucić ( $\$ 6$ rozporządzenia z dnia 3 VII 1948 r.).

${ }^{29} \mathrm{~W}$ stosunku do habilitacji przeprowadzanych w akademiach lekarskich podlegających ministrowi zdrowia rozporządzenie z 1948 r. kompetencje ministra oświaty w zakresie postępowań habilitacyjnych odnosiło także do ministra zdrowia, działającego jednakże w porozumieniu z ministrem oświaty. 
jej oceny rada wydziałowa powoływała komisję w składzie nie mniejszym niż trzech członków spośród profesorów i docentów szkół akademickich lub innych wybitnych pracowników naukowych czynnych w tej dziedzinie nauki, z której odbywała się habilitacja lub w dziedzinach pokrewnych. Przynajmniej jeden spośród członków komisji miał być powołany spoza grona nauczycielskiego uczelni, w której habilitacja się odbywała. Jednego spośród członków, należącego do składu rady wydziałowej, rada wyznaczała na przewodniczącego komisji i referenta sprawy $^{30}$. Na członkach komisji spoczywał obowiązek sporządzenia na piśmie recenzji pracy habilitacyjnej, w terminie zakreślonym przez radę wydziałową. Recenzja miała się kończyć wnioskiem ${ }^{31}$, czy recenzent ją sporządzający uznaje pracę za uzasadniającą kwalifikacje naukowe kandydata do nauczania w szkole akademickiej. Dla tej oceny należało także wziąć pod uwagę inne prace naukowe kandydata. Wszystkie recenzje miały być odczytane i przedyskutowane na posiedzeniu komisji. Jej pracę kończyło podjęcie uchwały w sprawie wniosku co do oceny pracy habilitacyjnej i jej przedstawienie (wraz z recenzjami i protokołem z posiedzenia komisji) radzie wydziałowej ${ }^{32}$;

2. dyskusję habilitacyjną - jej przeprowadzenie $z$ kandydatem było możliwe tylko w sytuacji pozytywnej oceny pracy habilitacyjnej, wyrażonej w drodze uchwały rady wydziałowej. Jeżeli rada nie odstąpiła od dyskusji habilitacyjnej (a mogła to uczynić w drodze wyjątku ze względu na uznaną pozycję naukową kandydata, o ile minister oświaty nie zarządził obowiązku jej odbycia), do udziału w niej zapraszała poza członkami rady wydziałowej i powołanymi członkami komisji spoza rady także profesorów i docentów wykładających dany przedmiot we wszystkich szkołach akademickich w kraju. W dyskusji habilitacyjnej mogli też uczestniczyć, zależnie od uznania rady wydziałowej, inni

${ }^{30}$ Niezależnie od oceny pracy przez komisję rada wydziałowa mogła się zwrócić do innych uczonych w kraju i za granicą o wyrażenie opinii na temat wartości naukowej pracy habilitacyjnej i innych publikacji naukowych kandydata. Mogła też w skład tej komisji powołać wybitnych praktyków z dziedzin odpowiadających specjalności naukowej, w liczbie nie większej niż jedna czwarta ogółu członków komisji ( $\$ 9$ ust. 1 ostatnie zdanie i ust. 2 rozporządzenia z 1948 r.).

${ }^{31}$ Ponadto recenzja miała być tak sformułowana, aby mogła być w istotnych częściach opublikowana $\mathrm{w}$ fachowym czasopiśmie naukowym. Minister oświaty mógł też zarządzić jej opublikowanie ( $\$ 10$ ust. 3 rozporządzenia z 1948 r.).

32 Radzie wydziałowej sprawozdanie z oceny pracy habilitacyjnej i innych prac naukowych kandydata przedstawiał wyznaczony przez nią referent sprawy. Rada wydziałowa nie była związana wnioskami komisji i recenzentów. 
pracownicy naukowi, czynni w tej samej dziedzinie nauki lub w dziedzinach pokrewnych, tudzież wybitni praktycy. W każdym przypadku celem dyskusji było stwierdzenie zdolności kandydata do obrony tez naukowych zawartych w pracy habilitacyjnej. Uczynienie zadość temu warunkowi stanowiło podstawę pozytywnej uchwały rady wydziałowej;

3. wykład habilitacyjny - jego publiczne wygłoszenie było możliwe jedynie w przypadku uznania wyniku dyskusji za pozytywny lub zwolnienia kandydata od tego obowiązku. Inaczej niż w rozwiązaniach wcześniejszych temat wykładu wybierał kandydat za zgodą rady wydziałowej z zakresu nauki, z której się habilitował, i miał być to wykład jednogodzinny. Wygłoszenie wykładu miało na celu wykazanie, że kandydat ma umiejętność wykładania na poziomie akademickim. Rada wydziałowa mogła kandydata od jego wygłoszenia zwolnić, jeżeli uznała, że ten w inny sposób wykazał umiejętności wykładania. O przyjęciu wykładu lub o jego odrzuceniu decydowała rada wydziałowa $w$ formie uchwały.

Wraz z pozytywną oceną wykładu habilitacyjnego (lub decyzją o zwolnieniu kandydata od jego wygłoszenia) rada wydziałowa stwierdzała zakończenie postępowania habilitacyjnego i postanawiała o nadaniu kandydatowi prawa nauczania. Uchwała ta wymagała zatwierdzenia przez ministra oświaty za zgodą Rady Głównej. Przepisy nie przewidywały środków ochrony prawnej w razie odmowy zatwierdzenia przez ministra uchwały rady wydziałowej o nadaniu kandydatowi prawa nauczania. Przyznawały je natomiast na poszczególnych etapach postępowania habilitacyjnego. Kandydatowi służyło odwołanie do ministra oświaty (za pośrednictwem dziekana) od negatywnych rozstrzygnięć: decyzji dziekana o odrzuceniu podania o habilitację; decyzji odmownych rady wydziałowej w sprawach: kwalifikacji osobistych kandydata, oceny pracy habilitacyjnej, wyniku dyskusji habilitacyjnej i oceny wykładu habilitacyjnego. Odwołanie rozstrzygał minister oświaty za zgoda Rady Głównej. W przypadku uwzględnienia odwołania minister za zgodą tej Rady mógł przekazać sprawę radzie wydziałowej do dalszego postępowania, ale też mógł zarządzić dalsze prowadzenie postępowania habilitacyjnego przez Radę Główną w jej własnym zakresie działania. W tym ostatnim przypadku Rada Główna podejmowała sprawę i prowadziła ją za pośrednictwem sekcji specjalnej, przy czym prezydium tej Rady mogło zarządzić powtórzenie stadiów postępowania już odbytych w radzie wydziałowej. Wyłącznie to drugie rozwiązanie mogło mieć 
także miejsce w następstwie uznania przez ministra oświaty zasadności zażalenia kandydata na przewlekłość (bez dostatecznego uzasadnienia) postępowania habilitacyjnego przed radą wydziałowa, po przeniesieniu przez ministra za zgodą Rady Głównej postępowania habilitacyjnego $z$ tej rady do Rady Głównej.

Niezależnie od powyższych powodów Rada Główna przeprowadzała habilitację we własnym zakresie działania również wtedy, gdy żadna ze szkół akademickich nie miała prawa habilitowania $\mathrm{z}$ danej gałęzi nauki, jak i w innych przypadkach, gdy na prośbę kandydata minister oświaty za zgodą Rady Głównej uznał to za wskazane. Osoby bezpośrednio przez tę Radę habilitowane minister oświaty przydzielał do odpowiednich szkół akademickich.

Bez względu na miejsce przeprowadzania habilitacji jej pomyślny przebieg wiązał się z nadaniem kandydatowi prawa nauczania. Prawo to miało obejmować całość pewnej nauki lub taką jej część, którą można było uważać za przedmiot w sobie zamknięty, i mogło dotyczyć tylko tej szkoły akademickiej, dla której zostało uzyskane, a w przypadku habilitacji przeprowadzanych przez Radę Główną - tej szkoły wyższej, do której minister przydzielił osobę habilitowaną.

Prawo nauczania $z$ tytułu habilitacji rodziło po stronie habilitanta prawo i obowiązek prowadzenia wykładów. Nie było to rozwiązanie nowe ${ }^{33}$. Dekret w swych rozwiązaniach poszedł dalej. Uznanie za równoważne z prowadzeniem wykładów także kierowanie przez docentów ćwiczeniami i pracami badawczymi pozostawił wyłącznie w gestii rady wydziałowej. I był to zabieg trafny, podyktowany przede wszystkim potrzebą stworzenia na danym wydziale elastycznych warunków dla wypełniania przez docenta etatowego jego wymiaru godzin dydaktycznych.

Prawo nauczania nie było prawem absolutnym, i podobnie jak w rozwiązaniach z pierwszych lat Polski Ludowej wygasało, jeżeli docent

${ }^{33}$ Zgodnie $z$ art. 1 ust. 2 i art. 2 dekretu z dnia 16 XI 1945 r. o stosunku służbowym i uposażeniu etatowych docentów szkół akademickich minister oświaty w związku z nominacją etatowych docentów (spośród docentów państwowych szkół akademickich na wniosek rady wydziałowej lub z własnej inicjatywy, po wysłuchaniu opinii tej rady) określał ich najniższy obowiązkowy wymiar godzin wykładów i ćwiczeń w tygodniu. Poza ich prowadzeniem, co najmniej w liczbie godzin oznaczonych aktem nominacji, obowiązkiem docenta etatowego była twórcza praca badawcza oraz egzaminowanie z wykładanego przedmiotu tylko w razie powołania go na egzaminatora. Minister mógł także, na wniosek rady wydziałowej, określić przedmiot obowiązkowych wykładów i ćwiczeń docenta etatowego. 
(1) nie korzystał z niego przez dwa następujące po sobie lata szkolne ${ }^{34}$, chyba że otrzymał urlop od ministra oświaty po wysłuchaniu opinii (a więc już nie na wniosek) rady wydziałowej; (2) został mianowany docentem etatowym albo profesorem nadzwyczajnym lub zwyczajnym na innym wydziale lub w innej szkole akademickiej. Na jego prośbę prawo to mogło być jednak utrzymane decyzją ministra oświaty za zgodą Rady Głównej.

Prawo nauczania mogło być także przeniesione, rozszerzone, ale też utracone i cofnięte. W sytuacji pierwszej nabyte prawo nauczania nadane w jednej ze szkół akademickich minister oświaty za zgodą Rady Głównej mógł przenieść na inny wydział lub do innej szkoły. Oznaczało to zarazem wygaśnięcie prawa nauczania w szkole wyższej, z której je przeniesiono. Sytuacja druga pozwalała na rozszerzenie prawa nauczania na inną dziedzinę wiedzy na mocy uchwały rady wydziałowej, zatwierdzonej przez ministra oświaty za zgodą Rady Głównej. Przy czym podstawą rozszerzenia mogła być tylko działalność naukowa $\mathrm{w}$ danej dziedzinie wiedzy. Utratę prawa nauczania uzasadniało zaniechanie przez docenta wykładów (w tym innych zajęć dydaktycznych). Minister oświaty mógł je jednak na jego prośbę przywrócić, ale mógł też, po wysłuchaniu opinii rady wydziałowej i Rady Głównej, prawo nauczania docentowi cofnać.

Dekret dość restrykcyjnie rozstrzygał kwestię osób, których postępowanie habilitacyjne nie zostało zakończone (zatem wcześniej wszczęte) przed dniem jego wejścia w życie, tj. przed dniem 30 października 1947 r. W art. 110 ust. 3 stanowił, że do czasu wydania rozporządzeń w nim przewidzianych (a więc nawet nie ich wejścia w życie) obowiązują w sprawach, które te rozporządzenia mają regulować, dotychczasowe przepisy (czyli postanowienia wydanych na podstawie ustawy z $1933 \mathrm{r}$. przepisów wykonawczych), ze zmianami wynikającymi z dekretu. Na mocy art. 62 ust. 9 dekretu minister oświaty wydał za zgodą Rady Głównej rozporządzenie z dnia 3 lipca 1948 r. ${ }^{35}$ regulujące postępowania habilitacyjne rad wydziałowych i Rady Głównej w ramach postanowień dekretu. W \& 20 tego rozporządzenia przyjął, że nie ma ono zastosowania do habilitacji wszczętych przed dniem wejścia w życie dekretu (ale i, co oczywiste, przed tą datą niezakończonych).

${ }^{34} \mathrm{O}$ organizacji studiów w latach szkolnych w miejsce lat akademickich zob. K. Wojtczak, Prawne determinanty procesu kształcenia w szkołach wyższych w latach 1920-1990 (Część II), „Studia Prawa Publicznego” 2014, nr 1(5), s. 72.

${ }^{35}$ Rozporządzenie to weszło w życie z dniem 26 VIII $1948 \mathrm{r}$. 
$\mathrm{W}$ istocie dekret z 1947 r. poza objętym nim polem regulacji pozostawił określenie statusu naukowego i zawodowego osób z doktoratem (starego typu) oraz z zakończonym przed tą datą postępowaniem habilitacyjnym. Podstawę do uporządkowania różnych tytułów i stopni naukowych nadawanych przepisami dotychczasowymi stworzyła dopiero ustawa z $1951 \mathrm{r}$. Poza zastrzeżeniem przyznawania tytułu naukowego docenta osobom ze stopniem kandydata nauk dopuszczała także możliwość przyznania tego tytułu naukowego pracownikom nauki szkół wyższych i instytutów naukowych z pomyślnie zakończonym postępowaniem doktorskim i habilitacyjnym przed jej wejściem w życie. Do przyznawania tego tytułu naukowego, do dnia 31 grudnia 1952 r., upoważniła Centralną Komisję Kwalifikacyjną dla Pracowników Nauki $(\mathrm{CKK})^{36}$. Jeszcze $\mathrm{w}$ grudniu tegoż roku na mocy dekretu ${ }^{37}$ termin ten zmieniono przez zastąpienie ogólnym sformułowaniem - w terminie, który określi Prezydium Rządu. Tego stanu prawnego nie zmieniła ustawa nowelizująca z 1956 r. ${ }^{38}$ Centralna Komisja Kwalifikacyjna dopiero w kwietniu 1953 r. ustaliła wytyczne w sprawie zasad przyznawania tytułu naukowego docenta i obwieszczeniem przewodniczącego tej Komisji ogłosiła je dwa miesiące później ${ }^{39}$.

W wytycznych CKK określiła warunki nabycia tytułu naukowego docenta ${ }^{40}$ przez osoby: (1) pełniące obowiązki samodzielnych

\footnotetext{
${ }^{36}$ Zob. art. 71 ust. 3 Ustawy z dnia 15 XII 1951 r. o szkolnictwie wyższym i o pracownikach naukowych (brzmienie pierwotne Dz.U. 1952 Nr 6, poz. 38).

${ }^{37}$ Zob. Dekret z dnia 24 XII 1952 r. o zmianie terminu przyznania tytułów naukowych dotychczasowym samodzielnym pracownikom nauki (Dz.U. Nr 53, poz. 348).

${ }_{38}$ Zob. art. 78 ust. 3 ustawy z 1951 r. w brzmieniu nadanym w 1956 r. (tekst jedn. Dz.U. Nr 45, poz. 205).

${ }^{39}$ Obwieszczenie Przewodniczącego Centralnej Komisji Kwalifikacyjnej dla Pracowników Nauki z dnia 27 VI 1953 r. dotyczące uchwały nr 2 Centralnej Komisji Kwalifikacyjnej dla Pracowników Nauki z dnia 29 IV 1953 r. w sprawie zasad przyznawania tytułu naukowego docenta (M.P. Nr 66, poz. 808). Wytyczne CKK w pierwszej kolejności określały warunki przyznawania tytułu naukowego docenta osobom posiadającym stopień kandydata nauk.

${ }^{40}$ Zgodnie z pkt I wytycznych "[z]asadniczym warunkiem przyznawania tytułu naukowego docenta jest posiadanie stopnia kandydata nauk". Tytuł ten mógł być zatem nadany osobie z niższym stopniem naukowym, odpowiadającej warunkom określonym $\mathrm{w}$ art. 52 ustawy, dającej rękojmię swą dotychczasową pracą naukową i dydaktyczna, że jako pracownik nauki, nauczyciel i wychowawca kadr socjalistycznej inteligencji będzie wykonywać swe obowiązki pracownika nauki zgodnie z potrzebami gospodarki i kultury narodowej. Od osoby pretendującej do tego tytułu oczekiwano nadto wykazania się umiejętnością kierowania pracą naukową oraz co najmniej pięcioletnią pracą na stanowisku adiunkta (pomocniczego pracownika nauki). CKK mogła tytuł ten przyznać
} 
pracowników nauki, (2) wyróżniające się w gronie pomocniczych pracowników nauki - zatrudnionych w szkołach wyższych lub instytutach naukowych. W ten sposób z pierwszej grupy o tytuł naukowy docenta mogły ubiegać się osoby posiadające tytuł doktora (starego typu), mające w swym dorobku naukowym pracę naukowa, odpowiadającą wymaganiom stawianym pracom kandydackim, wykonaną w okresie nie dłuższym niż trzy lata przed datą wystąpienia $\mathrm{z}$ wnioskiem o nadanie tytułu naukowego docenta, a także dotychczasowi docenci ( $z$ tytułem nie naukowym) oraz osoby posiadające habilitację. Objęci druga grupa mogli o tytuł ten ubiegać się, jeżeli w swym dorobku naukowym posiadali pracę naukową odpowiadającą wymaganiom określonym ogólnymi przepisami i uchwałą CKK dla prac kandydackich ${ }^{41} \mathrm{w}$ okresie nie dłuższym niż trzy lata przed datą wystąpienia $\mathrm{z}$ wnioskiem o nadanie tytułu naukowego docenta. Obu grupom postawiono warunek ograniczający czasowo złożenie wniosku do dnia 30 czerwca 1954 r.

\section{Habilitacja w Polskiej Rzeczypospolitej Ludowej}

\subsection{Wprowadzenie do rozważań}

Rok 1958 przyniósł nowe rozwiązania. Zmiany wprowadzone ustawą z tegoż roku o szkołach wyższych miały też walor głębszy. Po blisko czterdziestu latach od odzyskania przez Polskę niepodległości po raz pierwszy habilitacja prowadziła do nabycia wyższego stopnia naukowego (docenta). Ale też i po raz pierwszy stopień naukowy doktora był niższym stopniem naukowym. Stopień naukowy docenta nadawać mogły szkoły wyższe oraz placówki naukowe PAN, już w początku

również pomimo krótszego okresu pracy osobie, która uzyskała stopień naukowy kandydata nauk po ukończeniu studiów aspiranckich, o ile w czasie ich trwania wyróżniła się w pracy naukowej i praktyce dydaktycznej, a także osobie bez aspirantury naukowej, lecz mającej poważne doświadczenie w pracy zawodowej związanej z dyscypliną będącą przedmiotem pracy kandydackiej oraz umiejętność prowadzenia zajęć dydaktycznych. $\mathrm{O}$ aspiranturze naukowej zob. szerzej K. Wojtczak, O stopniach naukowych w Polsce Ludowej. Część 2. Organizacja aspirantury naukowej i studiów doktoranckich, "Studia Prawa Publicznego" 2016, nr 2(14), s. 49 i n.

${ }^{41}$ Wymagania w tym zakresie określała Uchwała nr 1 Centralnej Komisji Kwalifikacyjnej dla Pracowników Nauki z dnia 29 IV 1953 r. w sprawie zasad postępowania przy nadawaniu stopnia kandydata nauk, ogłoszona Obwieszczeniem Przewodniczącego Centralnej Komisji Kwalifikacyjnej dla Pracowników Nauki z dnia 27 IX 1953 r. (M.P. Nr 66, poz. 806). 
lat pięćdziesiątych uprawnione do nadawania prawem wtedy przewidzianych dwóch stopni naukowych - kandydata nauk (niższy stopień naukowy) ${ }^{42}$ oraz doktora nauk (wyższy stopień naukowy) ${ }^{43}$.

Ustawa z dnia 5 listopada 1958 r. o szkołach wyższych tylko w jej pierwotnym brzmieniu normowała warunki nadawania stopnia naukowego docenta i przebiegu przewodu habilitacyjnego. I choć ustawę z $1958 \mathrm{r}$. uchylono dopiero z dniem 1 września $1982 \mathrm{r}^{4}{ }^{44}$, rok 1965 diametralnie zmienił ten stan rzeczy ${ }^{45}$. Określanie odrębną ustawą spraw stopni naukowych skutkowało w 1965 r. skreśleniem przyjętego ustawą z 1958 r. działu IV. Stopnie naukowe (art. 77-87) ${ }^{46}$ oraz odesłaniem w tej i kolejnej jej noweli rad wydziałowych $\mathrm{w}$ nadawaniu stopni naukowych ${ }^{47}$ wprost do ustawy z 1965 r. o stopniach naukowych i tytułach naukowych $^{48}$. Nie bez uzasadnienia zatem ustawa z 1982 r. kwestii nadawania stopni naukowych praktycznie nie regulowała ${ }^{49}$.

Podobnie rzecz się miała w odniesieniu do Polskiej Akademii Nauk i instytutów naukowych i naukowo-badawczych istniejących poza szkołami wyższymi. Wobec Akademii ustawą z dnia 17 lutego 1960 r. ${ }^{50}$

${ }^{42} \mathrm{Na}$ temat niższych stopni naukowych nadawanych w Polsce Ludowej zob. K. Wojtczak, O stopniach naukowych w Polsce Ludowej, Część 1. Niższe stopnie naukowe, "Studia Prawa Publicznego" 2016, nr 3(15), s. 27 i n.

${ }^{43} \mathrm{O}$ wyższym stopniu naukowym doktora nauk zob. K. Wojtczak, W kwestii wyższego stopnia naukowego doktora, s. 33 i n.

${ }^{44} \mathrm{Na}$ mocy art. 232 pkt 1 ustawy z dnia 4 V 1982 r.

${ }^{45}$ Zmiana ta dotyczyła także wyższego szkolnictwa wojskowego. Ustawa z dnia 31 III 1965 r. o wyższym szkolnictwie wojskowym (Dz.U. Nr 14, poz. 102) w art. 18 wprost odsyłała do ustawy z 1965 r. o stopniach naukowych i tytułach naukowych.

${ }_{46}$ Zob. pkt 49 Ustawy z dnia 31 III 1965 r. o zmianie ustawy o szkołach wyższych (Dz.U. Nr 14, poz. 98). Ustawą tą zarazem zastąpiono dotychczasowy tytuł ustawy z 1958 r. - o szkołach wyższych tytułem nowym - o szkolnictwie wyższym (pkt 1).

${ }^{47}$ Zob. pkt 24 a) ustawy z 1965 r. o zmianie ustawy o szkołach wyższych oraz pkt 25 Ustawy z dnia 20 XII 1968 r. o zmianie ustawy o szkolnictwie wyższym (Dz.U. Nr 46, poz. 334).

${ }^{48}$ Również od 1965 r. udział Rady Głównej Szkolnictwa Wyższego w nadawaniu stopni naukowych miała określać ustawa o stopniach naukowych i tytułach naukowych (art. 1 pkt 8 ustawy z dnia 31 III 1965 r. o zmianie ustawy o szkołach wyższych).

${ }^{49} \mathrm{~W}$ swych rozwiązaniach uwzględniała zmianę wprowadzoną ustawą zmieniającą w 1968 r. ustawę o stopniach naukowych i tytułach naukowych (Dz.U. Nr 46, poz. 335) i odpowiednio zmianę ustawy o szkołach wyższych z 1958 r. (przez wprowadzenie w miejsce stopnia naukowego docenta stopnia naukowego doktora habilitowanego) i w konsekwencji z mocy art. 222 zachowywała stanowisko docenta przez osoby nieposiadające z dniem wejścia w życie ustawy z 1982 r. stopnia naukowego doktora habilitowanego.

${ }^{50}$ Ustawa z dnia 17 II 1960 r. o Polskiej Akademii Nauk (Dz.U. Nr 10, poz. 64). Ustawę tę uchylono z dniem 15 X 1997 r. na mocy Ustawy z dnia 25 IV 1997 r. o Polskiej Akademii Nauk (Dz.U. Nr 75, poz. 469). 
uchylono ustawę z dnia 30 października 1951 r. o Polskiej Akademii Nauk $^{51}$, a wraz z nia, na mocy jej art. 55 ust. 1 pkt 2, uchylono także art. 154 ustawy z 1958 r. o szkołach wyższych w zakresie dotyczącym PAN (pkt 1). Ustawa z dnia 17 lutego 1960 r. zachowała w zakresie działania Akademii kształcenie kadr pracowników nauki w jej placówkach naukowych i nadawanie stopni naukowych przewidzianych ustawą o szkołach wyższych (art. 4 pkt 5 ustawy). Po zmianie tej ustawy w $1965 \mathrm{r}^{52}$ placówki naukowe Akademii w zakresie nadawania stopni naukowych, w tym stopnia naukowego docenta, odsyłała wprost do przepisów o stopniach naukowych i tytułach naukowych.

$\mathrm{Z}$ kolei instytuty naukowe i naukowo-badawcze istniejące poza strukturą szkół wyższych podlegały nieco innemu reżimowi prawnemu, niezależnie od podstaw prawnych ich utworzenia przed rokiem $1958^{53}$. Ustawą z dnia 17 lutego $1961 \mathrm{r}$. o instytutach naukowo-badawczych ${ }^{54}$ uchylono Ustawę z dnia 8 stycznia 1951 r. o tworzeniu instytutów naukowo-badawczych dla potrzeb gospodarki narodowej. Zarazem na mocy jej art. $38 \mathrm{w}$ sprawach przekazanych do określenia w drodze przepisów wykonawczych miały obowiązywać do czasu ich wydania przepisy dotychczasowe, o ile nie pozostawały w sprzeczności z postanowieniami tejże ustawy. $W$ ten sposób wobec instytutów naukowych (naukowo-badawczych) zachowano w mocy art. 154 ustawy o szkołach wyższych znacznie dłużej aniżeli wobec PAN. W odniesieniu bowiem do nich (instytutów naukowych) art. 154 skreślono dopiero w 1965 r. nowelizacją ustawy z roku 1958 o szkołach wyższych ${ }^{55}$ oraz ustawą zmieniającą ustawę o instytutach naukowo-badawczych ${ }^{56}$. Tym samym od tego roku również instytuty naukowe działające poza strukturą szkół

${ }^{51}$ Dz.U. Nr 51, poz. 391.

${ }^{52}$ Zob. art. 35 Ustawy z dnia 31 III 1965 r. o zmianie ustawy o Polskiej Akademii Nauk (Dz.U. Nr 14, poz. 99).

${ }^{53}$ Mowa tu o instytutach działających na podstawie Ustawy z dnia 8 I 1951 r. o tworzeniu instytutów naukowo-badawczych dla potrzeb gospodarki narodowej (Dz.U. Nr 5, poz. 38); na podstawie art. 47 Ustawy z dnia 15 XII 1951 r. o szkolnictwie wyższym i o pracownikach nauki (Dz.U. 1956 Nr 45, poz. 205) albo na podstawie przepisów szczególnych zwane były instytutami resortowymi.

${ }^{54}$ Ustawa z dnia 17 II 1961 r. o instytutach naukowo-badawczych (Dz.U. Nr 12, poz. 60), istniejących poza szkołami wyższymi.

${ }^{55}$ Zob. pkt 68 ustawy z dnia 31 III 1965 r. o zmianie ustawy o szkołach wyższych.

${ }^{56}$ Zob. art. 1 pkt 14 Ustawy z dnia 31 III 1965 r. o zmianie ustawy o instytutach naukowo-badawczych (Dz.U. Nr 14, poz. 100). 
wyższych poddano także przepisom o stopniach naukowych i tytułach naukowych.

Wobec placówek naukowych PAN i instytutów naukowych (naukowo-badawczych) istniejących poza szkołami wyższymi przed datą uchylenia art. 154 ustawy o szkołach wyższych na mocy jego pkt 2 Rada Ministrów miała określić, w drodze rozporządzenia, tryb i organy właściwe do przeprowadzania przewodów habilitacyjnych oraz do nadawania przez nie stopni naukowych i ich zatwierdzania. I tę delegację ustawową rząd wypełnił w 1959 r. swym rozporządzeniem z dnia 28 lipca ${ }^{57}$, uchylonym dopiero z dniem 3 marca $1966 \mathrm{r}$. na mocy rozporządzenia rządu z dnia 8 lutego $1966 \mathrm{r}^{58}$ Do tego czasu rozporządzenie to miało więc w pełni zastosowanie zarówno do placówek naukowych PAN, jak i do instytutów naukowych (naukowo-badawczych).

\subsection{Postępowania habilitacyjne}

\subsubsection{Warunki uprawniające do nadawania stopnia naukowego docenta}

Powierzenie prawa habilitowania nie tylko państwowym ${ }^{59}$ szkołom wyższym, ale po raz pierwszy także placówkom naukowym PAN oraz innym instytutom naukowym wymagało określenia zakresu podmiotowego realizacji ich uprawnień, a dla każdej z tych instytucji kształcącej

${ }^{57}$ Rozporządzenie Rady Ministrów z dnia 28 VII 1959 r. w sprawie trybu nadawania stopni naukowych w placówkach naukowych Polskiej Akademii Nauk oraz instytutach istniejących poza szkołami wyższym (Dz.U. Nr 45, poz. 276).

${ }^{58}$ Rozporządzenie Rady Ministrów z dnia 8 II 1966 r. w sprawie warunków i trybu przeprowadzania przewodów doktorskich i habilitacyjnych (Dz.U. Nr 8, poz. 53).

${ }^{59}$ Zgodnie z art. 136 ustawy z 1958 r. Rada Ministrów na wniosek ministra zgłoszony po zasięgnięciu opinii Rady Głównej mogła prawo nadawania stopni naukowych przyznać również szkole wyższej niepaństwowej. I tak się stało. Prawo do habilitowania uzyskała Wyższa Szkoła Nauk Społecznych przy KC PZPR, na mocy Uchwały nr 40 Rady Ministrów z dnia 30 I 1960 r. w sprawie przyznania Wyższej Szkole Nauk Społecznych przy KC PZPR prawa nadawania absolwentom szkoły tytułu magistra oraz prawa nadawania stopni naukowych (M.P. Nr 15, poz. 66). Uchwałę tę uchylono Uchwałą nr 211 Rady Ministrów z dnia 7 X 1971 r. w sprawie przyznania Wyższej Szkole Nauk Społecznych przy Komitecie Centralnym Polskiej Zjednoczonej Partii Socjalistycznej prawa nadawania tytułów określonych w ustawie o szkolnictwie wyższym oraz stopni naukowych (M.P. Nr 50, poz. 319). 
i naukowej także wskazania, w zakresie jakich gałęzi nauk lub dyscyplin naukowych mógł być nadawany stopień naukowy docenta. Nabycie i zachowanie tego uprawnienia od szkół wyższych, PAN i instytutów naukowych wymagało ponadto stworzenia środowiska naukowego o odpowiednio wysokim poziomie ${ }^{60}$.

W kwestii pierwszej - szkoły wyższe mogły stopień naukowy docenta nadawać osobom będącym pracownikami nauki danego wydziału, innego wydziału, innej szkoły wyższej bądź placówki naukowej; placówki naukowe PAN i instytuty naukowe oraz naukowo-badawcze natomiast pracownikom działalności podstawowej zatrudnionym odpowiednio w PAN lub w jej placówkach bądź w instytutach naukowych istniejących poza szkołami wyższymi. W kwestii drugiej - stopień naukowy docenta mógł być nadawany na wydziałach szkół wyższych z zakresu dyscypliny naukowej bądź specjalności naukowej będącej przedmiotem przewodu habilitacyjnego, wchodzącej w skład głównych kierunków naukowych wydziału, w którym przeprowadzany był przewód habilitacyjny ${ }^{61}$. Nieco inaczej rzecz ujęto dla nadawania określonego w ustawie o szkołach wyższych stopnia naukowego docenta w placówkach PAN i instytutach naukowych (naukowo-badawczych) - z zakresu gałęzi nauki lub dyscypliny naukowej stanowiącej główny kierunek prac badawczych PAN, główny kierunek prac naukowo-badawczych instytutu. W kwestii trzeciej natomiast kryterium środowiska naukowego na odpowiednio wysokim poziomie określono przez wskazanie minimalnego progu zatrudnienia $^{62}$. Tylko te szkoły wyższe oraz placówki PAN i instytuty

${ }^{60}$ Warunki te określało Rozporządzenie Rady Ministrów z dnia 12 VI 1959 r. w sprawie warunków uprawniających szkoły wyższe, placówki naukowe Polskiej Akademii Nauk i instytuty istniejące poza szkołami wyższymi do nadawania stopni naukowych (Dz.U. Nr 35, poz. 218). Rozporządzenie to uchylono z dniem 3 III 1966 r. na mocy rozporządzenia Rady Ministrów z dnia 8 II 1966 r.

${ }^{61}$ Zob. \& 2 Zarządzenia Ministrów: Szkolnictwa Wyższego, Zdrowia, Oświaty, Spraw Zagranicznych oraz Przewodniczącego Głównego Komitetu Kultury Fizycznej z dnia 30 XI 1959 r. w sprawie bliższego określenia stopni naukowych doktora i docenta w zależności od gałęzi nauki lub dyscypliny naukowej (M.P. Nr 102, poz. 548).

${ }^{62}$ Kryterium środowiska naukowego dla wydziałów szkół wyższych w zakresie nadawania stopnia naukowego docenta wyznaczało: (1) posiadanie w swoim składzie co najmniej dwunastu zatrudnionych w pełnym wymiarze zajęć samodzielnych pracowników nauki, w tej liczbie co najmniej sześciu z tytułem profesora zwyczajnego lub nadzwyczajnego, a spośród nich co najmniej jednego profesora reprezentującego dyscyplinę naukową lub gałąź nauki odpowiadającą tematowi rozprawy habilitacyjnej (kryterium progu zatrudnienia). W danej szkole wyższej samodzielny pracownik 


\section{naukowe spełniające warunek odpowiednio wysokiego poziomu} swego środowiska naukowego mogły być ujęte wykazem i tylko te nim objęte mogły przeprowadzać przewody habilitacyjne i nadawać stopień naukowy docenta. Jeżeli szkoły wyższe oraz placówki PAN i instytuty naukowe (naukowo-badawcze) temu warunkowi przestały odpowiadać ${ }^{63}$, skreślano je $z$ wykazu ${ }^{64}$. Na mocy art. 4 ust. 3 ustawy z 1958 r. wykazy dla wydziałów szkół wyższych ustalał (w drodze zarządzenia) minister szkolnictwa wyższego. Tak jednoznacznej dyspozycji ustawa ta nie przyjęła natomiast wobec placówek PAN i instytutów naukowych (naukowo-badawczych). W art. 154 pkt 1 stanowiła jedynie, że "[d]o czasu wydania nowych przepisów o Polskiej Akademii Nauk oraz o instytutach naukowych (naukowo-badawczych) istniejących

nauki mógł być brany pod uwagę tylko jeden raz i tylko na wydziale, w skład którego wchodziła katedra, w której był zatrudniony, bądź na wydziale, na którym realizował główną część swoich obowiązków dydaktycznych. Sytuacje wątpliwe miał rozstrzygać senat. Wyjątek od tej zasady był możliwy. Przy ustalaniu samodzielnych pracowników nauki zatrudnionych w pełnym wymiarze zajęć było możliwe uwzględnienie również samodzielnych pracowników nauki zatrudnionych w połowie wymiaru zajęć, lecz pełniących funkcje w administracji dydaktyczno-naukowej szkoły, jak również członków PAN bez względu na wymiar zajęć; (2) to, że co najmniej połowa katedr wchodzących w skład wydziału była obsadzona przez samodzielnych pracowników nauki. W sposób bardzo zbliżony zdefiniowano kryterium środowiska naukowego dla placówek Akademii i instytutów naukowych. Tak jak dla wydziałów szkół wyższych wymagano spełnienia kryterium progu zatrudnienia w brzmieniu ustalonym dla szkół wyższych, a ponadto działania rad naukowych, w których stan liczbowy miał wynosić co najmniej piętnastu samodzielnych pracowników nauki, w tej liczbie co najmniej ośmiu z tytułem profesora zwyczajnego lub nadzwyczajnego ( $\$ 4$ ust. 1 pkt 2 i $\S 5$ ust. 1 pkt 2 Rozporządzenia Rady Ministrów z dnia 12 VI 1959 r. w sprawie warunków uprawniających szkoły wyższe, placówki naukowe Polskiej Akademii Nauk i instytuty istniejące poza szkołami wyższymi do nadawania stopni naukowych). Do kryterium progu zatrudnienia odwoływały się także ustawy: z 1960 r. o Polskiej Akademii Nauk (art. 35 ust. 1) i ustawa z 1961 r. o instytutach naukowo-badawczych (art. 30 ust. 1). Odnośne postanowienia przyjęto także dla akademii wojskowych utworzonych Ustawą z dnia 16 II 1960 r. o akademiach wojskowych (Dz.U. Nr 9, poz. 56); zob. też Rozporządzenie Rady Ministrów z dnia 4 X 1960 r. w sprawie uprawnień akademii wojskowych w zakresie nadawania stopni naukowych oraz warunków nadawania tych stopni (Dz.U. Nr 46, poz. 276 ze zm.).

${ }^{63}$ Dla stwierdzenia spełnienia przesłanki środowiska naukowego o odpowiednio wysokim poziomie wymagano opinii komisji złożonej z sześciu samodzielnych pracowników nauki powoływanych w liczbie trzech przez ministra szkolnictwa wyższego spośród członków Rady Głównej i przez prezydium PAN w pozostałej liczbie ( 86 ust. 1 rozporządzenia Rady Ministrów z dnia 12 VI 1959 r.).

${ }^{64}$ Zob. $§ 8$ ust. 1 rozporządzenia Rady Ministrów z dnia 12 VI 1959 r. 
poza szkołami wyższymi [...]" wykazy ustala się według przepisów dotychczasowych ${ }^{65}$. Tymczasem nowa ustawa o Polskiej Akademii Nauk z 1960 r. w art. 35 ust. 3 ustalenie wykazu jej placówek uprawnionych do nadawania stopnia naukowego docenta powierzyła Prezydium Akademii, zarazem skreśliła art. 154 pkt 1 ustawy z 1958 r. Stawiało to Polską Akademię Nauk w wyjątkowo uprzywilejowanej pozycji wobec szkół wyższych, a nawet wobec instytutów naukowych (naukowo-badawczych) działających poza szkołami wyższymi. W odniesieniu do tych drugich delegację $w$ tym zakresie zawierał art. 30 ust. 4 ustawy z dnia 17 lutego 1961 r. Do ustalenia takiego wykazu upoważniał on Radę Ministrów na wniosek właściwego ministra, w uzgodnieniu z sekretarzem naukowym PAN. Dla instytutów naukowych (naukowo-badawczych) wykazów uprawniających do nadawania stopnia naukowego docenta nie opublikowano w dziennikach promulgacyjnych z tego okresu. Dla PAN obowiązku takiego nie przewidziano.

${ }^{65}$ Słowa "według przepisów dotychczasowych” oznaczały więc: „według przepisów ustawy z dnia 15 XII 1951 r.". Ustawa ta zaś w art. 48 ustalenie wykazów dla szkół wyższych i ówczesnych instytutów i innych placówek naukowych powierzała Radzie Ministrów. Rada Ministrów mocą swojej uchwały nr 548 z dnia 9 VII 1952 r. w sprawie przekazania Polskiej Akademii Nauk niektórych placówek naukowych (M.P. Nr 63, poz. 953) instytucji tej przekazała podległe ministrowi szkolnictwa wyższego cztery placówki naukowe: Państwowy Instytut Biologii Doświadczalnej im. M. Nenckiego (utworzony na podstawie Dekretu z dnia 5 IX 1947 r. o upaństwowieniu Instytutu Biologii Doświadczalnej - Dz.U. Nr 60, poz. 329, w 1948 r. objęty pod nazwą Państwowy Instytut Biologii Doświadczalnej wykazem samodzielnych placówek naukowo-badawczych na mocy Rozporządzenia Rady Ministrów z dnia 27 VII 1948 r. w sprawie ustalenia wykazu samodzielnych placówek naukowo-badawczych - Dz.U. Nr 37, poz. 267); Instytut Badań Literackich (utworzony na podstawie rozporządzenia Rady Ministrów z dnia 24 VII 1948 r. - Dz.U. Nr 37, poz. 266 ze zm.); Państwowy Instytut Matematyczny (działający na podstawie rozporządzenia Rady Ministrów z dnia 20 XI 1948 r. - Dz.U. Nr 56, poz. 443) oraz Zakład Dendrologii i Pomologii (utworzony rozporządzeniem Rady Ministrów z dnia 18 VII 1951 r. - Dz.U. Nr 40, poz. 302). Uchwałą tą jednocześnie zatwierdzono uchwałę Prezydium Polskiej Akademii Nauk z dnia 24 V 1952 r., na mocy której instytuty te stały się jej samodzielnymi placówkami naukowymi uprawnionymi do nadawania ówczesnych stopni naukowych (kandydata nauk i doktora nauk). Dotychczasowe przepisy sprowadzały się także do ustalonych, na podstawie dekretu z 1947 r., wykazów uznających za samodzielne instytuty naukowo-badawcze na mocy Rozporządzenia Rady Ministrów z dnia 27 VII 1948 r. w sprawie ustalenia wykazu samodzielnych placówek naukowo-badawczych (Dz.U. Nr 37, poz. 267), ze zmianą wprowadzoną Rozporządzeniem Rady Ministrów z dnia 29 XII 1949 r. (Dz.U. Nr 3, poz. 8). 
W odniesieniu do szkół wyższych dwa pierwsze wykazy ${ }^{66}$ opublikowano z końcem listopada $1959 \mathrm{r}$. Na podstawie pierwszego $\mathrm{z}$ nich ${ }^{67}$ prawo nadawania stopnia naukowego docenta uzyskało w łącznej liczbie dziewięćdziesiąt wydziałów w trzydziestu jeden szkołach wyższych, w tym w: siedmiu uniwersytetach (Jagiellońskim, Łódzkim, Marii Curie-Skłodowskiej w Lublinie, im. Adama Mickiewicza w Poznaniu, Mikołaja Kopernika w Toruniu, Warszawskim oraz im. Bolesława Bieruta we Wrocławiu), siedmiu wyższych szkołach technicznych (politechnikach: Gdańskiej, Krakowskiej, Łódzkiej, Śląskiej im. Wincentego Pstrowskiego w Gliwicach, Warszawskiej, Wrocławskiej oraz Akademii Górniczo-Hutniczej w Krakowie), sześciu wyższych szkołach rolniczych (w Krakowie, Lublinie, Olsztynie, Poznaniu, Wrocławiu oraz Szkole Głównej Gospodarstwa Wiejskiego w Warszawie), jednej wyższej szkole ekonomicznej (Szkole Głównej Planowania i Statystyki w Warszawie), dziesięciu akademiach medycznych (wydziałach lekarskich - w Białymstoku, Gdańsku, Krakowie, Lublinie, Łodzi, Poznaniu, Warszawie i we Wrocławiu oraz w Pomorskiej Akademii Medycznej im. Generała Karola Świerczewskiego w Szczecinie i Śląskiej Akademii Medycznej im. Ludwika Waryńskiego). Wykaz ten uchylono zarządzeniem Ministra Szkolnictwa Wyższego z dnia 24 maja 1962 r. ${ }^{68}$ Wykazem nim wprowadzonym obniżono łączną liczbę wydziałów do osiemdziesięciu dwóch i do dwudziestu dwóch łączną liczbę szkół wyższych uprawnionych do nadawania stopnia naukowego docenta. Do połowy roku 1965 r. wykaz ten zmieniono cztery

${ }^{66} \mathrm{~W}$ treści obu zarządzeń w załączeniu ustalających wykazy szkół wyższych zarazem dookreślono ich uprawnienia do nadawania stopnia naukowego docenta przez przyjęcie równobrzmiącej treści: „Wydziały szkół wyższych wymienione w wykazie stanowiącym załącznik nr 2 do zarządzenia uprawnione są do przeprowadzania przewodów habilitacyjnych i nadawania stopnia naukowego docenta z zakresu dyscypliny naukowej lub specjalności naukowej wchodzących w skład głównych kierunków naukowych wydziału, pod warunkiem, że temat rozprawy habilitacyjnej odpowiada dyscyplinie naukowej lub gałęzi nauki reprezentowanej na wydziale przez jednego zatrudnionego w pełnym wymiarze zajęć profesora".

${ }^{67}$ Zob. załącznik nr 2 do Zarządzenia Ministrów: Szkolnictwa Wyższego, Zdrowia, Oświaty oraz Przewodniczącego Głównego Komitetu Kultury Fizycznej z dnia 30 XI 1959 r. w sprawie ustalenia wykazu wydziałów szkół wyższych uprawnionych do nadawania stopni naukowych (M.P. Nr 102, poz. 550).

${ }^{68}$ Zarządzenie Ministra Szkolnictwa Wyższego z dnia 24 V 1962 r. w sprawie wykazu szkół wyższych podlegających nadzorowi Ministra Szkolnictwa Wyższego, które uprawnione zostały do nadawania stopni naukowych (M.P. Nr 47, poz. 223). Zarządzenie to uchylono z dniem 1 IX 1982 r. na mocy ustawy z dnia 4 V 1982 r. o szkolnictwie wyższym. 
razy. W roku $1963^{69}$ rozszerzono go o dwa wydziały i dwie szkoły wyższe ekonomiczne (w Poznaniu i Sopocie). Kolejnym zarządzeniem z tegoż roku $^{70} \mathrm{z}$ czterech do pięciu powiększono liczbę wydziałów w Politechnice Śląskiej im. Wincentego Pstrowskiego w Gliwicach; w 1964 r. ${ }^{71}$ również z czterech do pięciu powiększono liczbę wydziałów w Akademii Górniczo-Hutniczej, a w 1965 r. ${ }^{72}$ w Wyższej Szkole Rolniczej w Krakowie uprawnieniem objęto dodatkowo jeden wydział, ponadto utworzono Wyższą Szkołę Rolniczą w Szczecinie z dwoma wydziałami.

Drugim z wykazów ${ }^{73}$ prawo do nadawania stopnia naukowego docenta na czas oznaczony (do dnia 31 grudnia 1962 r.), z zastrzeżeniem spełnienia warunku przewidzianego zarządzeniem ustalającym ten wy$\mathrm{kaz}^{74}$, uzyskało czternaście kolejnych wydziałów ośmiu szkół wyższych ${ }^{75}$.

${ }^{69}$ Zarządzenie Ministra Szkolnictwa Wyższego z dnia 21 I 1963 r. dotyczące zmiany zarządzenia z dnia 24 V 1962 r. w sprawie ustalenia wykazu szkół wyższych podlegających nadzorowi Ministra Szkolnictwa Wyższego, które uprawnione zostały do nadawania stopni naukowych (M.P. Nr 10, poz. 56).

${ }^{70}$ Zarządzenie Ministra Szkolnictwa Wyższego z dnia 30 IX 1963 r. dotyczące zmiany zarządzenia z dnia 24 V 1962 r. w sprawie ustalenia wykazu szkół wyższych podlegających nadzorowi Ministra Szkolnictwa Wyższego, które uprawnione zostały do nadawania stopni naukowych (M.P. Nr 77, poz. 381).

${ }^{71}$ Zarządzenie Ministra Szkolnictwa Wyższego z dnia 28 VII 1964 r. dotyczące zmiany zarządzenia z dnia 24 V 1962 r. w sprawie ustalenia wykazu szkół wyższych podlegających nadzorowi Ministra Szkolnictwa Wyższego, które uprawnione zostały do nadawania stopni naukowych (M.P. Nr 56, poz. 266).

72 Zarządzenie Ministra Szkolnictwa Wyższego z dnia 26 III 1965 r. dotyczące zmiany zarządzenia z dnia 24 V 1962 r. w sprawie ustalenia wykazu szkół wyższych podlegających nadzorowi Ministra Szkolnictwa Wyższego, które uprawnione zostały do nadawania stopni naukowych (M.P. Nr 17, poz. 72).

${ }^{73}$ Zob. załącznik nr 2 do Zarządzenia Ministrów: Szkolnictwa Wyższego, Zdrowia, Oświaty i Spraw Zagranicznych z dnia 30 XI 1959 r. w sprawie ustalenia wykazu wydziałów szkół wyższych uprawnionych na czas określony do nadawania stopni naukowych (M.P. Nr 102, poz. 549). Prawo wydziałów objętych tym wykazem wygasło z dniem 31 XII 1962 r.

${ }^{74}$ Wykazem uprawniającym do nadawania stopnia docenta na określony czas mogły być objęte tylko wydziały szkoły wyższej, i to wyłącznie te, które będąc właściwe dla danej dyscypliny naukowej, a nietworzące środowiska naukowego o odpowiednio wysokim poziomie do udziału w przewodzie habilitacyjnym, zaprosiły z głosem stanowczym samodzielnych pracowników nauki z jednoimiennych wydziałów innych szkól, a w razie braku takich wydziałów $-\mathrm{z}$ wydziałów pokrewnych lub z innych placówek naukowych w liczbie wyznaczonej dla szkół wyższych w zakresie nadawania stopnia naukowego docenta minimalnym progiem zatrudnienia ( $\$ 7$ rozporządzenia Rady Ministrów z dnia 12 VI 1959 r., \& 3 zarządzenia z dnia 30 XI 1959 r.). Tej samej treści postanowienie przewidywało także zarządzenie z dnia 24 V 1962 r.

${ }^{75}$ Dotyczyło to: Politechniki Gdańskiej, Politechniki Śląskiej im. Wincentego Pstrowskiego w Gliwicach, Szkoły Głównej Gospodarstwa Wiejskiego w Warszawie, Wyższej 
Zarząadzeniem z dnia 24 maja 1962 r. ${ }^{76}$ uprawniającym szkoły wyższe do nadawania stopnia docenta na czas określony - do dnia 31 grudnia 1965 r. - zmniejszono o dwa liczbę uprawnionych w 1959 r. wydziałów i obniżono do sześciu liczbę szkół wyższych ${ }^{77}$ - przez dodanie Wyższej Szkoły Rolniczej we Wrocławiu i objęcie trzech akademii medycznych (w Krakowie, Łodzi i Warszawie) odrębnym wykazem, wprowadzonym zarządzeniem z dnia 15 września $1962 \mathrm{r}^{78}$, uprawniającym je także do dnia 31 grudnia 1965 r. do nadawania stopnia naukowego docenta na prowadzonych przez nie wydziałach (farmaceutycznych). Wykaz wprowadzony zarządzeniem z dnia 24 maja 1962 r. zmieniono pięciokrotnie. Zmiany prowadziły do stopniowego rozszerzania liczby wydziałów i listy szkół wyższych. W 1963 r. ${ }^{79}$ wykaz ustalający jedną szkołę wyższą (Akademię Górniczo-Hutniczą w Krakowie) z jednym wydziałem uzupełniono kolejnym zarządzeniem z tegoż roku, z dnia 4 października ${ }^{80}$,

Szkoły Rolniczej w Poznaniu, Szkoły Głównej Planowania i Statystyki w Warszawie oraz akademii medycznych w Krakowie, Łodzi i Warszawie.

${ }^{76}$ Zarządzenie Ministra Szkolnictwa Wyższego z dnia 24 V 1962 r. w sprawie ustalenia wykazu wydziałów szkół wyższych podlegających nadzorowi Ministra Szkolnictwa Wyższego, które uprawnione zostały na czas określony do nadawania stopni naukowych (M.P. Nr 47, poz. 224). Zarządzeniem tym jednocześnie uchylono przepisy Zarządzenia Ministrów: Szkolnictwa Wyższego, Zdrowia, Oświaty i Spraw Zagranicznych z dnia 30 XI 1959 r. w sprawie ustalenia wykazu wydziałów szkół wyższych uprawnionych na czas określony do nadawania stopni naukowych, w zakresie wydziałów szkół wyższych podlegających Ministrowi Szkolnictwa Wyższego.

${ }^{77}$ Chodziło tu o: Politechnikę Gdańską, Politechnikę Śląską im. Wincentego Pstrowskiego w Gliwicach, Szkołę Główną Gospodarstwa Wiejskiego w Warszawie, Wyższą Szkołę Rolniczą w Poznaniu, Wyższą Szkołę Rolniczą we Wrocławiu oraz Szkołę Główną Planowania i Statystyki w Warszawie.

${ }^{78}$ Zarządzenie Ministrów Zdrowia i Opieki Społecznej oraz Szkolnictwa Wyższego z dnia 15 IX 1962 r. w sprawie ustalenia wykazów wydziałów akademii medycznych uprawnionych na czas określony do nadawania stopni naukowych (M.P. Nr 72, poz. 336). Zarządzeniem tym uchylono przepisy Zarządzenia Ministrów: Szkolnictwa Wyższego, Zdrowia, Oświaty i Spraw Zagranicznych z dnia 30 XI 1959 r. w sprawie ustalenia wykazu wydziałów szkół wyższych uprawnionych na czas określony do nadawania stopni naukowych, w części dotychczas obowiązującej. Zarządzenie to uchylono z dniem 1 IX 1982 r. na mocy ustawy z dnia 4 V 1982 r. o szkolnictwie wyższym.

${ }^{79}$ Zarządzenie Ministra Szkolnictwa Wyższego z dnia 23 V 1963 r. dotyczące zmiany zarządzenia w sprawie ustalenia wykazu szkół wyższych, podlegających nadzorowi Ministra Szkolnictwa Wyższego, które uprawnione zostały na czas określony do nadawania stopni naukowych (M.P. Nr 46, poz. 228).

${ }^{80}$ Zarządzenie Ministra Szkolnictwa Wyższego z dnia 4 X 1963 r. dotyczące zmiany zarządzenia w sprawie ustalenia wykazu szkół wyższych, podlegających nadzorowi Ministra Szkolnictwa Wyższego, które uprawnione zostały na czas określony do nadawania stopni naukowych (M.P. Nr 77, poz. 382). 
o jedną szkołę wyższą (Politechnikę Warszawską) z jednym wydziałem. W 1964 r. wprowadzono dwie kolejne zmiany. Wykazem załączonym do zarządzenia $\mathrm{z}$ dnia 24 lutego $^{81}$ dodano jeden wydział w Akademii Górniczo-Hutniczej w Krakowie, z kolei zarządzeniem z dnia 28 lipca ${ }^{82}-$ wykaz rozszerzono o jedną szkołę wyższą (Politechnikę Wrocławską) z dwoma wydziałami. W roku 1965 ostatnim wykazem, wydanym na podstawie ustawy z 1958 r., dodano dwa wydziały w Akademii Górniczo-Hutniczej w Krakowie oraz po jednym wydziale w trzech politechnikach (Gdańskiej, Łódzkiej i Wrocławskiej) ${ }^{83}$.

Tym samym do czasu ustalenia nowych wykazów szkół wyższych na podstawie ustawy o stopniach naukowych i tytułach naukowych uprawniono do nadawania stopnia naukowego docenta dwadzieścia pięć szkół wyższych na dziewięćdziesięciu ośmiu wydziałach ${ }^{84}$. Jednocześnie z tej liczby szkół dwanaście uzyskało nadto prawo nadawania stopnia docenta na czas określony na dwudziestu sześciu wydziałach. Odrębnym wykazem uprawniającym do nadawania stopnia naukowego docenta objęto dwa wydziały w niepaństwowej Wyższej Szkole Nauk Społecznych przy KC PZPR ${ }^{85}$.

Czy dla Polskiej Akademii Nauk ustalono wykazy jej placówek naukowych, trudno ustalić (wykazów Prezydium Akademii nie objęto powszechnym obowiązkiem promulgacji). Z pewnością do połowy lat

${ }^{81}$ Zarządzenie Ministra Szkolnictwa Wyższego z dnia 24 II 1964 r. dotyczące zmiany zarządzenia w sprawie ustalenia wykazu szkół wyższych, podlegających nadzorowi Ministra Szkolnictwa Wyższego, które uprawnione zostały na czas określony do nadawania stopni naukowych (M.P. Nr 16, poz. 73).

${ }^{82}$ Zarządzenie Ministra Szkolnictwa Wyższego z dnia 28 VII 1964 r. dotyczące zmiany zarządzenia w sprawie ustalenia wykazu szkół wyższych, podlegających nadzorowi Ministra Szkolnictwa Wyższego, które uprawnione zostały na czas określony do nadawania stopni naukowych (M.P. Nr 52, poz. 252).

${ }^{83}$ Zarządzenie Ministra Szkolnictwa Wyższego z dnia 26 III 1965 r. dotyczące zmiany zarządzenia w sprawie ustalenia wykazu wydziałów szkół wyższych, podlegających nadzorowi Ministra Szkolnictwa Wyższego, które uprawnione zostały na czas określony do nadawania stopni naukowych (M.P. Nr 17, poz. 71).

${ }^{84}$ Wykazem szkół wyższych nie objęto Katolickiego Uniwersytetu Lubelskiego, mimo nadal obowiązującej Ustawy z dnia 9 IV 1938 r. o nadaniu Katolickiemu Uniwersytetowi Lubelskiemu pełnych praw państwowych szkół akademickich (Dz.U. Nr 27, poz. 242).

${ }^{85}$ Na mocy Zarządzenia Ministra Szkolnictwa Wyższego z dnia 14 IV 1960 r. w sprawie ustalenia wykazu wydziałów Wyższej Szkoły Nauk Społecznych przy KC PZPR uprawnionych do nadawania stopni naukowych oraz bliższego określenia tych stopni (M.P. Nr 37, poz. 183) prawo prowadzenia przewodów habilitacyjnych i nadawania stopnia naukowego docenta uzyskały dwa wydziały tej szkoły: Wydział Ekonomiczny i Wydział Historyczno-Socjologiczny. 
sześćdziesiątych nie objęto nimi instytutów naukowych istniejących poza szkołami wyższymi. W odniesieniu do nich pierwsze z ustalonych wykazów opublikowano na podstawie ustawy o stopniach naukowych i tytułach naukowych ${ }^{86}$. Przyczynę tego stanu rzeczy trudno ustalić, zważywszy, że warunki uprawniające do nadawania stopnia naukowego docenta, warunki przebiegu przewodu habilitacyjnego, począwszy od jego wszczęcia, aż do zakończenia, prawodawca określił, stosowną uchwała, nie tylko dla szkół wyższych, ale i dla placówek naukowych PAN oraz instytutów naukowych, i wobec każdej z nich zdefiniował wyraźnie skutki prawne skreślenia z wykazu. Oczywiście, brak wykazu nie prowadził (bo nie mógł) do skreślenia, ale też nieobjęcie nim danej instytucji nie uprawniało jej do habilitowania. Nie oznacza to jednak negacji objęcia każdej z nich regulacją w zakresie warunków potrzebnych do nadawania stopni naukowych oraz warunków i trybu prowadzenia postępowań habilitacyjnych. I tę optykę uzasadnia dalsza analiza uwzględniająca w równej mierze, oprócz szkół wyższych, także prawem przewidziany udział placówek naukowych PAN i instytutów naukowych w procesie habilitowania.

Skreślenie z wykazu wydziału szkoły wyższej (ale też placówki naukowej PAN lub instytutu naukowego), skutkujące utratą uprawnień w zakresie nadawania stopnia naukowego docenta, musiało prowadzić do rozstrzygnięcia sytuacji osób, których przewody habilitacyjne zostały w nich wszczęte przed ich skreśleniem z wykazu. Tej wątpliwości w odniesieniu do wydziałów szkół wyższych prawodawca nie rozstrzygał w sposób gwarantujący realizację zasady pewności prawa. Wszczęte na wydziale szkoły wyższej przewody habilitacyjne mogły być dokończone pod warunkiem zaproszenia do udziału w przewodzie z głosem stanowczym takiej liczby samodzielnych pracowników nauki danej lub pokrewnej dyscypliny z innych wydziałów szkoły lub innych szkół wyższych bądź placówek naukowych, by liczbowy skład wydziału odpowiadał warunkom określonym w $\S 4$ rozporządzenia z dnia 12 czerwca

\footnotetext{
${ }^{86}$ Pierwszy wykaz jednostek uprawnionych do nadawania stopnia naukowego docenta, poza szkołami wyższymi, dotyczący placówek naukowych PAN oraz instytutów naukowo-badawczych opublikowano wydanym na podstawie ustawy o stopniach naukowych i tytułach naukowych Zarządzeniem Przewodniczącego Komitetu Nauki i Techniki z dnia 19 XI 1966 r. w sprawie ustalenia wykazu jednostek uprawnionych do nadawania stopni naukowych (M.P. Nr 66, poz. 314) - w odniesieniu do PAN; Zarządzeniem Przewodniczącego Komitetu Nauki i Techniki z dnia 18 I 1967 r. w sprawie ustalenia wykazu jednostek uprawnionych do nadawania stopni naukowych (M.P. Nr 7, poz. 33) - w odniesieniu do instytutów naukowo-badawczych.
} 
1959 r. (co najmniej dwunastu samodzielnych pracowników naukowych, w tej liczbie co najmniej sześciu $z$ tytułem naukowym profesora zwyczajnego lub nadzwyczajnego, a spośród nich co najmniej jednego reprezentującego dyscyplinę naukową lub gałąź nauki odpowiadająca tematowi rozprawy habilitacyjnej). Niewypełnienie tego warunku przez dany wydział stawiało więc kandydata $z$ wszczętym przez radę tegoż wydziału przewodem habilitacyjnym w wyjątkowo trudnej sytuacji. $\mathrm{O}$ wiele bardziej dyskusyjne rozwiązanie przyjęto w odniesieniu do placówek Akademii i instytutów. Wobec nich nie stawiano żadnego warunku dodatkowego, mimo że od nich dla nabycia uprawnienia do nadawania stopnia naukowego docenta także wymagano spełnienia przesłanki środowiska naukowego na odpowiednio wysokim poziomie (w tym warunku liczbowego składu rady naukowej). Tu wystarczyło jedynie to, że zapadła uchwała rady naukowej o dopuszczeniu kandydata do przewodu habilitacyjnego ( $\$ 8$ ust. 2 pkt 2 rozporządzenia $\mathrm{z}$ dnia 12 czerwca 1959 r.), co znajdowałoby uzasadnienie jedynie w sytuacji objęcia ich stosownym wykazem.

\subsubsection{Warunki i przebieg przewodów habilitacyjnych}

Ustawa z 1958 r. przeprowadzanie przewodów habilitacyjnych unormowała dość ogólnie ${ }^{87}$. Poza skąpym wskazaniem, kto może być dopuszczony do przewodu habilitacyjnego i z jakich etapów przewód ten jest złożony, oraz podaniem warunków uzasadniających podjęcie uchwały o nadaniu stopnia naukowego docenta i jej zatwierdzenia odsyłała do przepisów wykonawczych. Do ich wydania, w drodze rozporządzenia, upoważniała odpowiednio ministra szkolnictwa wyższego i rząd. Pierwsze z nich, odnoszące się wyłącznie do szkół wyższych, minister wydał z dniem 17 czerwca 1959 r. ${ }^{88}$, drugim zaś (z dnia 28 lipca 1959 r.) Rada

${ }^{87}$ Odrębnie uregulowano nabywanie stopnia naukowego docenta $\mathrm{w}$ akademiach wojskowych. Zob. Ustawę z dnia 16 II 1960 r. o akademiach wojskowych oraz Rozporządzenie Ministra Obrony Narodowej z dnia 10 X 1960 r. w sprawie przeprowadzania przewodów habilitacyjnych w akademiach wojskowych (Dz.U. Nr 46, poz. 278).

${ }^{88}$ Rozporządzenie Ministrów Szkolnictwa Wyższego, Zdrowia, Oświaty, Spraw Zagranicznych oraz Przewodniczącego Głównego Komitetu Kultury Fizycznej z dnia 17 VI 1959 r. w sprawie przeprowadzania przewodów habilitacyjnych w szkołach wyższych (Dz.U. Nr 41, poz. 256), uchylone z dniem 3 III 1966 r. Rozporządzeniem Rady Ministrów z dnia 8 II 1966 r. w sprawie warunków i trybu przeprowadzania przewodów doktorskich i habilitacyjnych (Dz.U. Nr 8, poz. 53). 
Ministrów określiła tryb nadawania stopni naukowych w placówkach naukowych PAN oraz instytutach naukowych istniejących poza szkołami wyższymi.

W ten sposób stworzono prawne uwarunkowania uwzględniające pewną różnicę $\mathrm{w}$ realizacji prawa szkół wyższych i placówek naukowych PAN oraz istniejących poza nią i szkołami wyższymi instytutów naukowych do nadawania stopnia naukowego docenta. Dla pierwszych $\mathrm{z}$ nich prawo nadawania stopni naukowych pozostawiono w gestii rad wydziałów, dla drugich - ich radom naukowym.

Stopień naukowy docenta mógł być nadany w szkole wyższej osobie będącej pracownikiem nauki danego wydziału lub innego wydziału w innej szkole wyższej bądź placówki naukowej, w PAN i w instytutach naukowych odpowiednio pracownikiem działalności podstawowej Akademii lub jej placówki, pracownikiem danego instytutu lub innego instytutu tego samego resortu $-\mathbf{z}$ zastrzeżeniem spełnienia następujących warunków: po pierwsze - złożenia podania (wraz z wymaganymi załącznikami $)^{89}$ o wszczęcie przewodu habilitacyjnego; po drugie - przedłożenia dowodu stwierdzającego posiadanie stopnia naukowego doktora oraz wykazania swoich osiągnięć naukowych; po trzecie - podjęcia przez radę (wydziału, naukową) decyzji o dopuszczeniu do przewodu habilitacyjnego; po czwarte - ukończenia tego przewodu z pomyślnym wynikiem.

Ustawa oraz wydane na jej podstawie przepisy wykonawcze przewodem habilitacyjnym objęły:

1. ocenę kwalifikacji naukowych kandydata na podstawie całego jego dorobku naukowego, ze szczególnym uwzględnieniem rozprawy habilitacyjnej. W odróżnieniu od rozwiązań wcześniej przyjętych

${ }^{89}$ Składający w szkole wyższej podanie miał do niego dołączyć: życiorys, dowód stwierdzający posiadanie stopnia naukowego doktora, rozprawę habilitacyjna, informację o dotychczasowej pracy naukowej oraz wykaz publikowanych prac naukowych z dołączonymi w miarę możliwości egzemplarzami tych prac. Nieco inaczej ujęte rozwiązanie przyjęto w odniesieniu do podań składanych w placówkach naukowych PAN i instytutach naukowych. Poza dołączeniem życiorysu wymagano: dowodu uzyskania stopnia doktora, rozprawy habilitacyjnej w pięciu egzemplarzach, wykazu prac naukowych oraz w miarę możliwości co najmniej po jednym egzemplarzu prac naukowych publikowanych i co najmniej po trzy egzemplarze prac naukowych niepublikowanych. W szkołach wyższych podanie o wszczęcie przewodu habilitacyjnego należało złożyć dziekanowi właściwego wydziału, w przypadku pracownika danego wydziału - za pośrednictwem kierownika katedry; pracownika innego wydziału, innej szkoły wyższej bądź placówki naukowej za pośrednictwem dziekana lub kierownika placówki naukowej. 
znacznie mocniej i wyraźniej podkreślono zatem wagę oceny dorobku naukowego, zgodnie z art. 83 ust. 2 ustawy stanowiącego twórczy wkład do rozwoju danej gałęzi nauki, oraz rozprawy habilitacyjnej, zgodnie z postanowieniami obu rozporządzeń z 1959 r. stanowiącej taki sam wkład. Przyjęcie przez ustawę i jej przepisy wykonawcze tego samego kryterium ocennego dla całokształtu osiągnięć naukowych kandydata złożonego z jego dorobku naukowego i rozprawy habilitacyjnej - stawiało między nimi znak równości. A zatem w równym stopniu miało też podlegać ocenie recenzentów. I założenie to w pełni przyjęto rozporządzeniem z dnia 28 lipca 1959 r. w odniesieniu do placówek naukowych PAN i instytutów naukowych ( $\$ 16$ ust. $4^{90}$ ). Tymczasem w odniesieniu do szkół wyższych rozporządzeniem z dnia 17 czerwca 1959 r. wprowadzono nieco odmienne rozwiązanie. Wprawdzie i tu ocena obu komponentów osiągnięć naukowych kandydata miała stanowić dla komisji powołanej przez radę wydziału ${ }^{91}$ podstawę do sformułowania wniosku pozwalającego radzie na podjęcie decyzji w sprawie wszczęcia przewodu habilitacyjnego, a wraz z nią wyznaczenia recenzentów dla oceny osiągnięć naukowych kandydata, jednak w istocie od recenzentów oczekiwano oceny rozprawy habilitacyjnej zakończonej wnioskiem w sprawie dopuszczenia kandydata do kolokwium habilitacyjnego ( $\$ 8$ ust. $3^{92}$ ). Rada wydziału wyznaczała trzech recenzentów spośród profesorów zwyczajnych lub nadzwyczajnych. Jednym z nich miał być samodzielny pracownik nauki z tytułem profesora zwyczajnego lub nadzwyczajnego, a w razie braku takiego - docent z innej szkoły wyższej lub placówki naukowej. Niemal analogiczne rozwiązanie przyjęto dla placówek PAN i instytutów naukowych. Odpowiednia rada naukowa miała powoływać co najmniej trzech recenzentów spośród profesorów zwyczajnych lub nadzwyczajnych, z których co najmniej jeden nie mógł był pracownikiem danej placówki Akademii lub instytutu. W obu wypadkach po zapoznaniu się z oceną i wnioskami recenzentów rada (wydziału, naukowa) podejmowała decyzję o dopuszczeniu kandydata do kolokwium habilitacyjnego.

${ }^{90}$ Zgodnie z nim „[ $[\mathrm{d}] \mathrm{o}$ oceny rozprawy habilitacyjnej i całego dorobku naukowego $[\ldots]$ rada naukowa powołuje recenzentów [...]".

${ }^{91}$ Zgodnie z $\S 8$ ust. 1 rozporządzenia z dnia 17 VI 1959 r. skład tej komisji tworzyło trzech profesorów zwyczajnych lub nadzwyczajnych, wyznaczonych przez radę wydziału.

${ }_{92}$ Recenzenci mieli opracować i przedstawić radzie wydziału, najpóźniej w ciągu trzech miesięcy, swoją ocenę rozprawy habilitacyjnej zakończoną wnioskiem w sprawie dopuszczenia kandydata do kolokwium habilitacyjnego. 
Rozprawa habilitacyjna miała być przedłożona w języku polskim, a w języku obcym, wraz z dołączonym obszernym jej streszczeniem w języku polskim, tylko za zezwoleniem odpowiedniej rady (wydziału, naukowej), i miała być opublikowana (ogłoszona drukiem) przed wszczęciem przewodu habilitacyjnego. Warunek drugi w szkole wyższej spełniało także przedłożenie, za zgodą rady wydziału, rozprawy opublikowanej w innej formie niż ogłoszona drukiem, umożliwiającej szerokie jej udostępnienie zainteresowanym. W placówkach naukowych PAN oraz w instytutach naukowych natomiast warunkowi temu czyniło zadość także przyjęcie rozprawy do publikacji. Wyjątki od tej zasady były jednak możliwe. W szkołach wyższych wszczęciu przewodu habilitacyjnego nie stało na przeszkodzie przedłożenie rozprawy habilitacyjnej w maszynopisie (w trzech egzemplarzach). Podjęcie przez radę wydziału uchwały o nadaniu stopnia naukowego docenta bez ogłoszenia rozprawy drukiem bądź opublikowania w innej formie umożliwiającej jej szerokie udostępnienie nie było jednak możliwe. Ale i od tej zasady możliwe były wyjątki. Minister na wniosek rady wydziału w przypadkach uzasadnionych mógł zwolnić od obowiązku publikacji rozprawy w całości lub w części. Z kolei w placówkach naukowych Akademii i w instytutach odpowiednia rada naukowa mogła zwolnić kandydata od wymogu publikacji rozprawy jedynie wtedy, gdy jej opublikowanie pozostawałoby w sprzeczności z obowiązkiem zachowania tajemnicy państwowej.

Rozprawa habilitacyjna mogła być przyjęta lub odrzucona. Rozprawa habilitacyjna odrzucona przez radę naukową nie dawała podstawy do ubiegania się o nadanie stopnia docenta w innych placówkach Akademii, instytutach naukowych lub wydziałach szkół wyższych. W odniesieniu do szkół wyższych takiego zastrzeżenia prawodawca nie wprowadził;

2. kolokwium habilitacyjne miało stanowić dyskusję nad rozprawą habilitacyjną i wykazać znajomość przez osobę ubiegającą się o nadanie stopnia naukowego docenta aktualnej problematyki dyscypliny naukowej stanowiącej zakres habilitacji. Kolokwium odbywało się na posiedzeniu rady wydziału (rady naukowej) i kończyło podjęciem przez odpowiednią radę decyzji co do jego wyniku. Ocena wyniku kolokwium mogła być pozytywna lub negatywna. W razie pozytywnej oceny rada wydziału (rada naukowa) orzekała o dopuszczeniu do wykładu habilitacyjnego. Ocena negatywna wyłącznie radzie wydziału zezwalała na ponowne jego przeprowadzenie $\mathrm{w}$ ustalonym przez nią terminie;

3. wykład habilitacyjny miał na celu stwierdzenie umiejętności zwięzłego i jasnego przedstawienia przez kandydata zagadnień naukowych. 
I nie było tu różnicy w przepisach dotyczących szkół wyższych i Akademii oraz instytutów naukowych. Różnica dotyczyła natomiast sposobu wyboru tematu wykładu habilitacyjnego i terminu publicznego posiedzenia poświęconego jego wygłoszeniu. W szkole wyższej kandydat przedstawiał radzie wydziału do wyboru dwa tematy wykładu habilitacyjnego. Tematem wykładu wygłoszonego mógł być jeden z nich, zatwierdzony przez radę wydziału. W PAN i instytutach naukowych kandydat prezentował wykład na temat przez siebie wybrany, zatwierdzony przez radę naukową. W szkole wyższej, Akademii i instytutach naukowych wygłoszenie wykładu wprawdzie odbywało się na publicznym posiedzeniu rady (wydziału, naukowej), jednak w szkole wyższej wyznaczano w tym celu specjalne posiedzenie rady wydziału. Obie rady (wydziału i naukowa) mogły zwolnić kandydata od wygłoszenia wykładu habilitacyjnego. Jeżeli z prawa tego nie skorzystały - wyłącznie rada wydziału dla wygłoszenia wykładu wyznaczała termin jej posiedzenia (specjalnego);

4. powzięcie przez radę wydziału (radę naukową) uchwały o nadaniu stopnia naukowego docenta (określonej gałęzi nauki lub dyscypliny naukowej). Podjęcie uchwały w tym zakresie poprzedzały uchwały rady (wydziału, naukowej) związane z przeprowadzeniem każdego z etapów przewodu habilitacyjnego (oceną rozprawy habilitacyjnej i całego dorobku naukowego kandydata, wynikiem kolokwium habilitacyjnego i wykładu habilitacyjnego, jeśli rada nie zwolniła kandydata od jego wygłoszenia). W szkole wyższej uchwały te zapadały w głosowaniu tajnym bezwzględną większością głosów specjalistów danej gałęzi nauki biorących udział z głosem stanowczym w posiedzeniu ${ }^{93}$ (bez określenia kworum), uchwała o nadaniu stopnia naukowego docenta ponadto z zastrzeżeniem warunku - obecności co najmniej dwóch trzecich uprawnionych do głosowania członków rady wydziału. W placówkach PAN i instytutach naukowych do ważności uchwał wymagano obecności

${ }^{93} \mathrm{~W}$ posiedzeniach rady wydziału, na których dokonywano czynności objętych przewodem habilitacyjnym, brali udział z głosem stanowczym zaproszeni przez radę wydziału co najmniej dwaj samodzielni pracownicy nauki, specjaliści danej dyscypliny naukowej z innych szkół wyższych bądź placówek naukowych. Jeżeli ubiegający się o stopień naukowy docenta był pracownikiem wydziału lub placówki naukowej nieposiadającej prawa do nadawania stopnia naukowego docenta, wśród zaproszonych specjalistów powinien być samodzielny pracownik nauki z tytułem profesora zwyczajnego lub nadzwyczajnego bądź docent tego wydziału lub placówki naukowej ( 3 ust. 2 rozporządzenia z dnia 17 VI 1959 r.). 
co najmniej połowy ogólnej liczby uprawnionych do głosowania ${ }^{94}$, nie mniej jednak niż dziesięciu osób. Uchwały miały zapadać większością dwóch trzecich głosów.

Uchwały rady (wydziału, naukowej) o nadaniu stopnia naukowego docenta wymagały zatwierdzenia. W szkołach wyższych zatwierdzenie uchwały rady wydziału $\mathrm{w}$ tym zakresie należało do ministra szkolnictwa wyższego (na wniosek rektora ${ }^{95}$ ) po zasięgnięciu opinii (a więc już nie za zgodą $\left.{ }^{96}\right)$ Rady Głównej ${ }^{97}$. O swojej decyzji minister zawiadamiał rektora ${ }^{98}$. W razie odmownej uchwały rady kandydatowi służyło odwołanie do ministra, który decydował po zasięgnięciu opinii Rady Głównej. Przy uwzględnieniu odwołania minister powierzał ponowne przeprowadzenie przewodu habilitacyjnego radzie wydziałowej innej szkoły wyższej. Natomiast w placówkach PAN oraz instytutach naukowych uchwała rady naukowej o nadaniu stopnia naukowego docenta wymagała zatwierdzenia przez Centralną Komisję Kwalifikacyjną dla Pracowników Nauki, utworzoną na mocy ustawy z 1951 r. Zgodnie z \& 23 rozporządzenia z dnia 28 lipca 1959 r. również ta Komisja

${ }^{94}$ Grupę osób uprawnionych tworzyli: członkowie rady naukowej będący samodzielnymi pracownikami nauki oraz zaproszeni przez tę radę w liczbie co najwyżej dwóch inni wybitni specjaliści z danej gałęzi nauki, będący samodzielnymi pracownikami nauki, w tym recenzent, niebędący pracownikiem danej placówki PAN lub instytutu ( $\$ 18$ ust. 1 rozporządzenia z dnia 28 VII 1959 r.).

${ }^{95}$ Do wniosku należało dołączyć: rozprawę doktorska, odbitki prac naukowych, wykaz publikacji, akta osobowe kandydata oraz odpisy wszystkich ocen komisji i recenzentów, a także protokołów z posiedzeń rady wydziału dotyczących całego przebiegu przewodu habilitacyjnego ( $\$ 15$ ust. 2 rozporządzenia z dnia 17 VI 1959 r.).

${ }^{96}$ Zob. też Uchwałę nr 387 Rady Ministrów z dnia 21 VIII 1959 r. w sprawie Regulaminu Rady Głównej Szkolnictwa Wyższego (M.P. Nr 83, poz. 437).

${ }^{97}$ W Wyższej Szkole Nauk Społecznych przy KC PZPR niezbędne było zasięgnięcie opinii Rady Wyższej Szkoły Nauk Społecznych przy KC PZPR ( 5 ust. 2 uchwały nr 40 Rady Ministrów z dnia 30 I 1960 r.), w szkołach artystycznych - Rady Wyższego Szkolnictwa Artystycznego, zgodnie z jej regulaminem (Uchwała nr 370 Rady Ministrów z dnia 5 XII 1962 r. w sprawie regulaminu Rady Wyższego Szkolnictwa Artystycznego - M.P. $\mathrm{Nr} 85$, poz. 398), a w akademiach wojskowych nadto - w zakresie nauk wojskowych przez ministra obrony narodowej po zasięgnięciu opinii Rady Wyższej Szkolnictwa Wojskowego, w zakresie nauk medycznych przez ministra szkolnictwa wyższego oraz ministra zdrowia po zasięgnięciu opinii Rady Głównej.

${ }^{98}$ Nazwiska osób, którym nadano stopień naukowy docenta, ogłaszano w Dzienniku Urzędowym Ministerstwa Szkolnictwa Wyższego. Nie było to rozwiązanie nowe. Ogłoszenia wskazujące na osoby, które w okresie Polski międzywojennej nabyły wyższy stopień naukowy doktora oraz tytuły profesora zwyczajnego lub nadzwyczajnego w zakresie określonej nauki publikowano w Dzienniku Urzędowym Ministra Wyznań Religijnych i Oświecenia Publicznego w dziale Ruch Służbowy. 
miała rozstrzygać odwołania od uchwał rady naukowej odmawiających wszczęcia przewodu habilitacyjnego lub nadania stopnia naukowego docenta. Zważywszy, że ustawa z 1958 r. o szkołach wyższych odstąpiła od instytucji Centralnej Komisji Kwalifikacyjnej (do której powróciła dopiero w 1973 r. już ze zmienionym dookreśleniem - do Spraw Kadr Naukowych ${ }^{99}$ ), powierzenie w 1959 r. jej uprawnień w tym zakresie było wyborem nieuprawnionym, niemającym umocowania prawnego. Rozwiązanie tego problemu przyniosła dopiero ustawa z 1960 r. o Polskiej Akademii Nauk konstytuująca Komisję Kwalifikacyjną Pracowników Nauki, a także wydany na mocy jej art. 40 ust. 2, w drodze uchwały Rady Ministrów, regulamin ${ }^{100}$. Wątpliwości takich nie budziło natomiast powierzenie Centralnej Komisji Kwalifikacyjnej dla Pracowników Nauki do rozpatrzenia, na podstawie przepisów dotychczasowych, sprawy dotyczącej nadania tytułu naukowego docenta ${ }^{101}$ do niej skierowanej przed dniem wejścia w życie ustawy z 1958 r. (art. 150 ust. 1 tego aktu).

\section{Podsumowanie}

W okresie objętym analizą prowadzenie postępowań habilitacyjnych zawsze należało do państwowych szkół wyższych. Tego stanu rzeczy nie zmieniło ani przyznanie w 1947 r. prawa habilitowania Radzie Głównej Szkolnictwa Wyższego, ani powierzenie z końcem 1958 r. prawa przeprowadzania przewodów habilitacyjnych placówkom naukowym Polskiej Akademii Nauk oraz instytutom naukowym działającym poza szkołami wyższymi. Liczba szkół wyższych uprawnionych do

${ }^{99}$ Zob. pkt 19a Ustawy z dnia 12 IV 1973 r. o zmianie przepisów dotyczących stopni naukowych i tytułów naukowych oraz organizacji instytutów badawczych (Dz.U. Nr 12, poz. 89).

${ }^{100}$ Uchwała nr 166 Rady Ministrów z dnia 23 V 1960 r. w sprawie regulaminu Komisji Kwalifikacyjnej Pracowników Nauki (M.P. Nr 45, poz. 217), uchylająca Uchwałę nr 339 Rady Ministrów z dnia 26 IV 1952 r. w sprawie regulaminu Centralnej Komisji Kwalifikacyjnej dla Pracowników Nauki (M.P. Nr A-42, poz. 601). Zgodnie z § 3 pkt 1 załącznika do uchwały nr 166 z 1960 r. do zakresu działania tej Komisji należało zatwierdzanie uchwał i rozstrzyganie odwołań w sprawie stopni naukowych w tym zakresie, w jakim według dotychczasowych przepisów należało to do Centralnej Komisji Kwalifikacyjnej dla Pracowników Nauki.

${ }^{101}$ Na mocy ustawy z dnia 15 XII 1951 r. oraz Rozporządzenia Rady Ministrów z dnia 26 IV 1952 r. w sprawie warunków i trybu nadawania stopni naukowych (Dz.U. Nr 24, poz. 164) tytuł naukowy docenta mógł być przez CKK zatwierdzony po przesłaniu do niej niezaskarżonej decyzji rady wydziału o nadaniu stopnia naukowego doktora nauk. 
habilitowania nie była jednak niezmienna. Zależała od wielu czynników: istniejącej bazy szkół wyższych o wydziałowej strukturze organizacyjnej, posiadających własną kadrę profesorską prowadzącą badania naukowe, początkowo tylko w zakresie gałęzi nauki reprezentowanej przez jedna z $z$ katedr danego wydziału, później gałęzi rozszerzonej o nauki pokrewne, od 1958 r. gałęzi nauki lub dyscypliny naukowej wchodzącej w skład głównych kierunków naukowych danego wydziału. Podobnie rzecz się miała w odniesieniu do placówek naukowych Polskiej Akademii Nauk i instytutów naukowych istniejących poza szkołami wyższymi. Granice ich samodzielności wyznaczały prace naukowe prowadzone zgodnie z planem prac Akademii, instytutu, przez samodzielnych pracowników nauki z zakresu gałęzi nauki lub dyscypliny naukowej stanowiącej główny kierunek prac badawczych danej placówki PAN lub instytutu.

W prawie szkół wyższych postępowania habilitacyjne podlegały różnym reżimom prawnym obowiązującym: w pierwszych latach po zakończeniu II wojny światowej (1945-1947), w okresie umacniania socjalistycznego ustroju i pozycji władzy ludowej (1947-1951) oraz w czasie dalszego rozwoju Polskiej Rzeczypospolitej Ludowej nacechowanym licznymi reformami zakończonymi procesem transformacji ustrojowej i społecznej (1958-1990). W pierwszym okresie prawo habilitowania oparto na rozwiązaniach z lat trzydziestych Polski międzywojennej, z niewielkimi zmianami wprowadzonymi w 1945 r. przez ówczesne Ministerstwo Oświaty. W roku 1947 r. wdrożono pierwszą reformę szkolnictwa wyższego, znacznie osłabiającą pozycję rad wydziałowych szkół wyższych w zakresie postępowań habilitacyjnych na rzecz wzmocnienia pozycji ministra oświaty, w szczególności kompetencyjnej samodzielności (bardzo szerokiej) Rady Głównej Szkolnictwa Wyższego. W okresie najsilniejszego wpływu wzorców radzieckich (w latach 1951-1958) w Polsce odstąpiono od habilitacji, do której wraz z osłabieniem siły wpływu komunistycznej ideologii powrócono z końcem 1958 r. Do 1965 r. warunki i przebieg postępowań habilitacyjnych normowało prawo szkół wyższych. Od roku 1965 warunki habilitowania poddano odrębnej regulacji - ustawie o stopniach naukowych i tytułach naukowych. Nie bez uzasadnienia zmiany ustawy z 1958 r. dokonane po 1965 r. oraz wprowadzenie ustawy z 1982 r. wraz z jej zmianami po tym roku normowały sprawy związane $z$ habilitacją jedynie $w$ zakresie potrzebnym do określenia statusu zawodowego osób ze stopniem naukowym docenta, od 1968 r. doktora habilitowanego. 
W okresach badanych określone prawem szkół wyższych etapy przebiegu postępowania (od 1958 r. przewodu) habilitacyjnego, poza ich poprzedzeniem jedynie $\mathrm{w}$ dwóch pierwszych okresach $(1945,1947)$ badaniem kwalifikacji osobistych kandydata, w istocie wiele się nie różniły. Objęto nimi: (1) ocenę kwalifikacji naukowych kandydata (od 1947 r. ocenę wartości naukowej rozprawy habilitacyjnej i innych publikacji kandydata, od 1958 r. ocenę kwalifikacji naukowych kandydata na podstawie całego jego dorobku naukowego, ze szczególnym uwzględnieniem rozprawy habilitacyjnej), (2) dyskusję habilitacyjną (od 1958 r. kolokwium habilitacyjne) oraz (3) wygłoszenie wykładu habilitacyjnego. Wyraźne różnice sprowadzały się natomiast do przewidzianych prawem wymagań, w szczególności w zakresie zbadania kwalifikacji naukowych kandydata i oceny rozprawy habilitacyjnej oraz warunków jej recenzowania, a także zakresu dopuszczalnych zwolnień od wymagań stawianych przed kandydatem przed wszczęciem postępowania habilitacyjnego, jak i w jego trakcie.

Mimo podobieństwa kolejności etapów postępowań habilitacyjnych i wymagań stawianych kandydatom ubiegającym się o wszczęcie tego postępowania jego pomyślne zakończenie nie dawało im równych szans na drodze awansu naukowego i zawodowego. Niejednolitość rozwiązań sprowadzała się do nadawania prawa wykładania (veniam legendi), od 1947 r. prawa nauczania, wraz z tytułem docenta szkoły wyższej przyznającej to prawo, począwszy od 1958 r. stopnia naukowego docenta (etatowego), od 1968 r. doktora habilitowanego. To zróżnicowanie stopni i tytułów dla osoby o nie ubiegającej się nie pozostawało bez znaczenia także $z$ innego powodu. Tylko stopnie (a nie tytuły) naukowe mogły być nostryfikowane.

Te, w istocie szczegółowo prawem określone, procedury habilitowania wprawdzie były adresowane do szkół wyższych, a od 1958 r. także do placówek naukowych PAN i instytutów naukowych istniejących poza szkołami wyższymi, jednak nie każde z nich objęto wykazami uprawniającymi do nadawania stopni naukowych. 


\section{HABILITATION DEGREES IN THE POLISH PEOPLE'S REPUBLIC. PART 1. THE REQUIREMENTS AND CONDITIONS OF HABILITATION PROCEEDINGS UNDER THE LAW ON SCHOOLS OF HIGHER EDUCATION}

\section{S u m mary}

Until 1965 the requirements and conditions of habilitation proceedings in Poland were governed by the law on schools of higher education. The solutions adopted under that law showed a relatively high degree of stability. In the first years after WWII the habilitation qualification was based on the solutions governing in Poland in the 1930s, with only slight changes introduced in the first month after the end of the war. The first reform of higher education of 1947 left the right to confer habilitation degrees with schools of higher education then in existence and retained the existing order of the habilitation proceedings. However, it implemented a number of rather significant amendments in the area of the requirements needed to be fulfilled at each stage of these proceedings. The right to lecture remained inherent to the habilitation qualification and degree. What changed was the scope of influence of the minister of education supervising schools of higher education regarding habilitation proceedings and the appointment of the Main Council of Higher Education with the right of final say and consent to the opening of the habilitation qualification and to run the habilitation proceedings.

Habilitation was abandoned by the reform of 1951 and replaced, following the Soviet model, with a higher degree of a doctor of science. Further changes followed in 1958 when it was restored by relevant provisions of the Act on higher education. It was then that more than forty years after Poland regained independence, the habilitation degree was for the first time tied to a successful completion of the habilitation proceedings and earning the degree of a 'docent'. The Main Council of Higher Education continued to function but its role in habilitation proceedings was reduced to issuing opinions before the minister of higher education decided on habilitation matters. Apart from schools of higher education, the right to confer habilitation degrees was granted to the Polish Academy of Sciences and academic institutions operating outside schools of higher education.

Keywords: the People's Poland - habilitation procedure - the Polish People's Republic - habilitation proceedings - conditions entitling to open habilitation proceedings 